\title{
Ocena wpływu aranżacji garażu na wynik symulacji CFD rozprzestrzeniania się dymu i ciepła
}

\author{
The Influence of the Arrangement of Passenger Cars in Indoor Car Parks \\ on CFD Calculations
}

\section{Оценка влияния устройства подземного паркинга на результаты CFD-моделирования распространения дыма и тепла}

\begin{abstract}
ABSTRAKT
Cel: Celem pracy jest przedstawienie wyników badań dotyczących określenia wpływu rozmieszczenia w przestrzeni garażu pojazdów osobowych w określonych miejscach parkingowych na uzyskane w symulacjach numerycznych CFD wartości parametrów fizycznych, w tym masowej koncentracji dymu oraz pola prędkości przepływu. Aby dokonać rozmieszczenia samochodów w sposób losowy, stworzono program komputerowy wykorzystujący metodę pseudolosowego doboru parametrów i lokalizacji pojazdów.

Projekt i metody: Obliczenia numeryczne wykonane w ANSYS FLUENT v.14.5.

Wyniki: Analiza wyników pozwala stwierdzić, że wielkości wirów dymu i gazów pożarowych oraz prędkości, jakie osiągają po uformowaniu się w obrębie garażu mają istotny wpływ na masową koncentrację dymu w analizowanym obszarze. W obliczeniach zaobserwowano również, że w przypadku scenariuszy uwzględniających taką samą liczbę pojazdów, istotny wpływ na sposób oceny ma fakt, w jakim miejscu zostaje ukształtowana główna struga powietrza dopływająca z szachtu nawiewnego

Wnioski: W przypadku garaży o skomplikowanym kształcie lub niskich (poniżej 2,9 m) rekomenduje się wykonanie dodatkowych obliczeń numerycznych uwzględniających różną liczbę i rozmieszczenie pojazdów w garażu. Wykonanie dodatkowych symulacji można ograniczyć do przypadków, w których zajętość miejsc parkingowych w garażu będzie wynosiła 0\% (jedynie z samochodem, z którego inicjowany jest pożar), 40-50\% i 100\%. Podane obłożenie stanowisk wynika z przeanalizowanych serii obliczeń, gdy różnice w wynikach były najbardziej zauważalne i istotne w procesie oceny.

Różnice w wynikach pomiędzy scenariuszami będą większe, gdy pożar będzie się rozwijał z większą mocą i w rezultacie wydzieli się więcej dymu i ciepła w przestrzeni garażu. Dlatego istotne jest, by w takim przypadku przed przystąpieniem do obliczeń numerycznych, dokonać oceny ryzyka wpływu zajętości miejsc postojowych na końcowe wyniki. Z przedstawionych w niniejszym opracowaniu symulacji wynika, że już przy pożarach rzędu 1,4 MW w początkowej ich fazie rozwoju istotnie mogą zmieniać się warunki panujące w garażu. W sytuacji, gdy prędkości na kratach nawiewu mechanicznego wynoszą ponad 2,5 m/s, a w najbliższej okolicy szachtu kompensacyjnego znajdują się zaparkowane pojazdy, wówczas obliczenia numeryczne należatoby wykonać dla pustego garażu, jak również dla scenariusza z samochodami zaparkowanymi w tych newralgicznych punktach. Uzyskane z takiej serii obliczeń wyniki mogą się znacząco różnić, więc zasadne jest, by w analizach uwzględniać tego rodzaju przypadki.

Słowa kluczowe: wentylacja pożarowa, garaże zamknięte, wentylacja strumieniowa, symulacje CFD

Typ artykułu: oryginalny artykuł naukowy
\end{abstract}

Przyjęty: 10.12.2018; Zrecenzowany: 17.12.2018; Zatwierdzony: 21.12.2018;

Identyfikatory ORCID autorów: P. Suchy - 0000-0002-6661-7404; W. Węgrzyński - 0000-0002-7465-0212;

Procentowy wkład merytoryczny: P. Suchy - 70\%; W. Węgrzyński - 30\%;

Proszę cytować: BiTP Vol. 52 Issue 4, 2018, pp. 118-139, https://dx.doi.org/10.12845/bitp.52.4.2018.8;

Artykuł udostępniany na licencji CC BY-SA 4.0 (https://creativecommons.org/licenses/by-sa/4.0/)

\section{ABSTRACT}

Aim: The aim of this study is to present the results of research on the influence of the arrangement of passenger cars in specific parking spaces inside an indoor car park on the numerical values obtained in CFD simulations of physical parameters such as smoke density and air/smoke stream velocity. In order to distribute cars randomly, a computer program was developed using a pseudorandom method to determine the type of vehicle as well as the position of the car in the indoor car park.

Project and methods: CFD calculations in Ansys Fluent 14.5

Results: On analysis, the results demonstrate that the size of vortices and their velocity after forming inside the indoor car park space have a significant impact on the mass concentration of smoke in the analysed area. In the course of the calculations, it was also observed that in comparing scenarios 
with the same number of vehicles, the method of assessment is significantly affected by the location of formation of the main air stream arriving from the air supply duct.

Conclusions: In the case of indoor car parks with a complicated shape or low height, less than $2.9 \mathrm{~m}$, it is recommended to perform additional numerical calculations taking into account different numbers of vehicles and their locations in the indoor car park. Additional simulations can be limited to cases where the occupancy of parking spaces in the indoor car park will be $0 \%$ (except for the car being the ignition source), $40-50 \%$ and $100 \%$. The provided occupancy rates are based on the analysed calculation series, where the differences in the results were the most noticeable and significant in the assessment process.

Scenario results will vary more if the fire curves initiated at the beginning have higher HRR and as a result more smoke and heat are released within the indoor car park. Therefore, in such cases, it is important to assess the risk of impact of the parking space occupancy rate on the results before proceeding to final numerical calculations. The simulations presented in this study demonstrate that at 1.4MW fires in the initial phase of fire development, the conditions prevailing in the indoor car park can change significantly. In a situation where the velocities on the mechanical ventilation grilles are over 2.5 $\mathrm{m} / \mathrm{s}$, and parked vehicles are located in the vicinity of the compensation inlet, it is important to perform numerical calculations for an empty indoor car park as well as for the scenario with cars parked at these crucial points. The results obtained from this series of calculations may vary significantly, so it is reasonable to include such cases in the analyses.

Keywords: CFD simulations, fire ventilation, indoor car park, thrust ventilation

Type of article: original scientific article

Received: 10.12.2018; Reviewed: 17.12.2018; Accepted: 21.12.2018;

Authors' ORCID IDs: P. Suchy - 0000-0002-6661-7404; W. Węgrzyński - 0000-0002-7465-0212;

Percentage contribution: P. Suchy - 70\%; W. Węgrzyński - 30\%;

Please cite as: BiTP Vol. 52 Issue 4, 2018, pp. 118-139, https://dx.doi.org/10.12845/bitp.52.4.2018.8;

This is an open access article under the CC BY-SA 4.0 license (https://creativecommons.org/licenses/by-sa/4.0/).

\section{АННОТАЦИЯ}

Цель: Целью данной работы является представление результатов исследований по определению влияния размещения пассажирских транспортных средств на определенных парковочных местах на значения физических параметров CFD для численного моделирования, включая массовую концентрацию дыма и поле скорости потока. Чтобы случайным образом расположить автомобили, была создана компьютерная программа с использованием псевдослучайного метода выбора параметров и местоположения автомобилей.

Проект и методы: Численные расчеты, сделанные в ANSYS FLUENT v.14.5.

Результаты: Анализ результатов позволяет сделать вывод о том, что размер вихрей дыма и дымовыхгазов, а также скорости, которых они достигают после формирования на подземной парковке, оказывают существенное влияние на массовую концентрацию дыма в анализируемой зоне. В расчетах также было отмечено, что в случае сценариев, учитывающих одинаковое количество транспортных средств, способ формирования основного воздушного потока, поступающего из вентиляционного канала, оказывает существенное влияние на метод оценки. Выводы: в случае подземных парковок сложной формы или низких (менее 2,9 м) рекомендуется выполнять дополнительные численные расчеты с учетом различного количества и распределения транспортных средств на парковке. Выполнение дополнительного моделирования может быть ограничено случаями, когда занятость парковочных мест в гараже будет равна 0\% (только с автомобилем, от которого начался пожар), 40-50\% и 100\%. Данное размещение на парковке является результатом анализа серии расчетов, когда различия в результатах в процессе оценки были наиболее заметными и значительными.

Различия в результатах между сценариями будут большими, когда огонь будет развиваться с большей мощностью, и в результате на парковке будет выделяться больше дыма и тепла. Поэтому важно, чтобы в таком случае, прежде чем приступить к численным расчетам, была проведена оценка риска влияния занятости парковочных мест на окончательные результаты. Моделирование, представленное в этом исследовании, показывает, что уже при пожарах 1,4 МВт на начальной стадии их развития условия, существующие на парковке, могут значительно измениться. В ситуации, когда скорости на механических вентиляционных решетках превышают 2,5 м / с, а в непосредственной близости от компенсационного канала находятся припаркованные транспортные средства, следует проводить численные расчеты для пустого паркинга, а также для сценария с автомобилями, припаркованными в этих критических точках. Результаты, полученные вследствие такой серии расчетов, могут существенно отличаться, поэтому целесообразно включать в анализ такие случаи.

Ключевые слова: противопожарная вентиляция, закрытые гаражи, струйная вентиляция, CFD-моделирование (газодинамический расчёт) Вид статьи: оригинальная научная статья

Принята: 10.12.2018; Рецензирована: 17.12.2018; Одобрена: 21.12.2018;

Идентификаторы ORCID авторов: P. Suchy - 0000-0002-6661-7404; W. Węgrzyński - 0000-0002-7465-0212;

Процентное соотношение участия в подготовке статьи: P. Suchy - 70\%; W. Węgrzyński - 30\%;

Просим ссылаться на статью следующим образом: BiTP Vol. 52 Issue 4, 2018, pp. 118-139, https://dx.doi.org/10.12845/bitp.52.4.2018.8;

Настоящая статья находится в открытом доступе и распространяется в соответствии с лицензией CC BY-SA 4.0 (https://creativecommons.org/

licenses/by-sa/4.0/). 


\section{Wprowadzenie}

Symulacje numeryczne CFD są obecnie popularnym narzędziem używanym w inżynierii bezpieczeństwa pożarowego przy projektowaniu i weryfikacji skuteczności działania systemów wentylacji oddymiającej. Wcześniej obliczenia dla takich instalacji opierano jedynie na uproszczonych wyrażeniach matematycznych i modelach analitycznych, które zostały opisane m.in. w [1, 2]. W dobie coraz bardziej zawansowanych i skomplikowanych pod względem architektury i konstrukcji budynków, możliwości te są niestety mocno ograniczone i niewystarczające do prawidłowego zaprojektowania systemu wentylacji pożarowej. Ze względu na ciągłe udoskonalanie programów komputerowych wykorzystujących obliczeniową mechanikę płynów projektanci coraz chętniej sięgają po to narzędzie, aby zweryfikować prawidłowość zastosowanych rozwiązań technicznych w opracowywanej przez siebie dokumentacji.

Inżynierowie wykonujący obliczenia numeryczne zdają sobie sprawę, że uzyskanie prawidłowych wyników zależy od wiernego odwzorowania w przygotowanym uprzednio modelu numerycznym rzeczywistych warunków panujących w rozpatrywanym obiekcie budowlanym. Do tej pory w symulacjach CFD prowadzonych dla garaży panowało przekonanie, że właściwym scenariuszem są obliczenia dla pustego obiektu - tzn. tylko z jednym lub trzema pojazdami, z których zostaje zainicjowany pożar.

Należy zastanowić się, czy takie podejście jest słuszne. Możliwe, że przeszkoda, jaką stanowi samochód zaparkowany w pobliżu np. szachtu nawiewnego, spowoduje tak istotną zmianę w prędkości strugi powietrza kompensacyjnego, że w wyniku pożaru powstanie inny rozkład masowej koncentracji dymu i jego pola prędkości w garażu. W niniejszej pracy podjęto próbę oceny wpływu takich zjawisk na końcowe wyniki symulacji w garażach wyposażonych w system wentylacji strumieniowej.

\section{Analiza literatury. Przyjęta metoda obliczeń i źródła danych}

\section{Modelowanie pożarów w garażach}

W przedmiotowej literaturze związanej z zagadnieniami dotyczącymi pożarów w garażach zamkniętych można zaobserwować, iż podstawowym celem dociekań naukowych i eksperymentów w tym obszarze jest uzyskanie informacji o parametrach fizycznych takich jak: pole temperatury, ilość generowanej sadzy, szybkość rozwoju pożaru, otrzymywanych na podstawie badań rzeczywistych pożarów różnego rodzaju pojazdów osobowych. W tym obszarze należy przede wszystkim wyróżnić raporty BRE nr BD2552 [3] i EUR 20466 EN [4], a także pracę M.L. Janssens [5]. W pierwszym dokumencie [3] zaprezentowano wyniki badań w skali rzeczywistej dotyczące m.in. pożarów od jednego do czterech pojazdów osobowych. Pożary te inicjowane były w różnych miejscach (np. wewnątrz samochodu, pod maską) oraz pod wpływem promieniowania cieplnego. Dzięki tym eksperymentom uzyskano dane dotyczące krzywych pożaru oraz maksymalnych temperatur zarejestrowanych

\section{Introduction}

CFD numerical simulations are currently a popular tool used in fire safety engineering to design and verify the effectiveness of smoke exhaust ventilation systems. Previously, calculations for such systems were based only on simplified mathematical expressions and analytical models described, i.a., in [1, 2]. In a time of increasingly advanced buildings of ever higher architectural and structural complexity, these capabilities are unfortunately severely limited and insufficient to correctly design a fire ventilation system. With the continuous development of software suites using fluid mechanics computations, designers increasingly often use this tool to verify the suitability of the technical solutions used in their documentation.

Engineers performing numerical calculations are aware that obtaining correct results is conditional on the faithful representation within a pre-developed numerical model of the real conditions present in the analysed civil structure. To date, CFD simulations performed for indoor car parks were influenced by the belief that the suitable scenario for calculations involves the empty structure, i.e. featuring no more than one to three vehicles representing the ignition source.

The suitability of this approach should be reconsidered. It is possible that the obstacle created by a car parked near, e.g. an air supply duct, causes such a significant change in the speed of the compensation air stream that a different distribution of the mass concentration of smoke and its velocity field inside the indoor car park can result. This paper attempts to assess the influence of such phenomena on the final simulation results in indoor car parks equipped with a jet ventilation system.

\section{Literature Review. The Adopted Calculation Method and Data Sources}

\section{Modelling fires in indoor car parks}

It can be observed that the literature on the subject of fires in indoor car parks primarily focuses its scientific studies and experiments on obtaining information regarding such physical parameters as the temperature field, the amount of soot generated and the speed of fire development, obtained on the basis of real fires of various types of passenger vehicles. In this respect, BRE reports No. BD2552 [3] and EUR 20466 EN [4], as well as M.L. Janssens' work [5] are particularly worth mentioning. The first document [3] presents the results of real-world scale studies regarding fires of one to four passenger vehicles. These fires were initiated in various locations (e.g. inside the car, under the hood) and were caused by heat. These experiments enabled the researchers to obtain data on the fire curves and the maximum temperatures recorded during the tests. In addition, the document presents the results of measurements of ignition time for 
w testach. Dodatkowo w dokumencie przedstawiono wyniki pomiarów czasu zapłonu różnych elementów pojazdów osobowych (opony, zderzak, bak, wykładziny) w zależności od wartości promieniowania cieplnego. Natomiast w drugiej w wymienionych publikacji [4] opisano pożary testowe samochodów, które zostały wykonane zarówno w garażach otwartych, jak i zamkniętych. Uzyskano informacje dotyczące krzywych pożarów i określono utraconą w wyniku pożaru masę pojazdów. Dokonano również pomiarów temperatur panujących w danym garażu podczas eksperymentu oraz ich wpływu na konstrukcję budynku np. ugięcia belek stalowych, przemieszczenia słupów. Praca M.L. Janssensa [5] zawiera z kolei podsumowanie wyników badań dotyczących pożarów pojazdów osobowych w pełnej skali wykonanych przez różne ośrodki z całego świata. Wspomniane powyżej publikacje stanowią bogate źródło danych wykorzystywanych w analizach CFD.

Drugim ważnym kierunkiem badań jest weryfikacja programów komputerowych opartych na obliczeniowej mechanice płynów poprzez porównanie wyników uzyskanych z obliczeń numerycznych np. z parametrami pochodzącymi z rzeczywistych doświadczeń. Tutaj należy wspomnieć o publikacjach: [6], w której na podstawie danych pochodzących m.in. z raportu BD2552 [3] wykonano symulacje numeryczne w programach BRANZFIRE i FDS oraz dokonano porównania wyników. Podobną metodę oceny zastosowano $w$ dokumentach [7] $\mathrm{i}$ [8]. W publikacji [7] badano wpływ ilości usuwanego powietrza i mocy pożaru na rozprzestrzenianie się dymu w garażach zamkniętych. Opisano pożary testowe o mocy od $200 \mathrm{~kW}$ do $4 \mathrm{MW}$, przy czym źródłem ognia i dymu była taca o wymiarach $3 \times 1,5 \times 0,5 \mathrm{~m}$ wypełniona wodą i heksanolem. Pomimo faktu, że źródłem pożaru było ciekłe paliwo (alkohol), a nie pojazd, to ze względu na odpowiednio dobrane parametry paliwa, dym rozprzestrzeniał się w garażu testowym podobnie jak przy pożarze rzeczywistego samochodu. Eksperymenty te odtworzono potem w programie FDS i przedstawiono w publikacji [8]. W kolejnych artykułach $[9,10]$ opisano użycie programu FDS również do odtworzenia wcześniej przeprowadzonych badań. Dla [9] punktem odniesienia były badania pożarów rzeczywistych pojazdów wykonane przez BRE i zaprezentowane w [3] - m.in.: pożar trzech sąsiadujących ze sobą samochodów w garażu wyposażonym w tryskacze. Natomiast w [10] przedstawiono wyniki symulacji CFD wykonanych na podstawie własnych eksperymentów w pełnej skali - źródło pożaru inicjowane wewnątrz przedziału pasażerskiego, bagażnika czy też pod maską pojazdu.

W przedstawionych powyżej przypadkach, do symulacji CFD w poszczególnych modelach parkingów na miejscach postojowych umieszczano najczęściej od 1 do 3 pojazdów osobowych (lub źródeł pożaru imitujących pojazd [8] i [9]). Samochody te zgodnie z normą BS 7346-7 [11] i dostępną wiedzą techniczną stanowią źródła pożaru o mocy ok. $4 \mathrm{MW}$ w przypadku pojedynczego pojazdu w garażu z tryskaczami lub ok. $8 \mathrm{MW}$ dla 2-3 zajętych obok siebie miejsc parkingowych przy braku instalacji tryskaczowej. Z kolei pozostałe dostępne na danej kondygnacji miejsca parkingowe są pozostawiane puste. $W$ badaniach naukowych skupiających się na porównaniu wyników symulacji z badaniami eksperymentalnymi takie uproszczenie jest jak najbardziej zasadne. W praktycznym zastosowaniu symulacji various elements of passenger vehicles (tyres, bumper, fuel tank, carpet) depending on heat radiation value. The second of the abovementioned publications [4] describes test fires of cars, which were performed both in unenclosed and enclosed (indoor) car parks. Information regarding fire curves was obtained and the weight of lost vehicles due to the fire was determined. Measurements of temperatures and their influence on the building's structure (e.g. bent steel beams, displaced posts) were also performed for analysed indoor car parks during the experiment. The study by M.L. Janssens [5] provides a summary of the results of studies regarding passenger vehicle fires in full scale performed by various centres from across the world. The abovementioned publications are a rich source of data for CFD analysis.

Another important purpose of research is to verify computer software based on fluid mechanics computations by comparing the results obtained in numerical calculations with e.g. parameters measured in real-life experiments. The following publications should be mentioned here: [6], which takes data from, i.a., report BD2552 [3] to perform numerical simulations in BRANZFIRE and FDS software and compare the results. A similar assessment method was used in documents [7] and [8]. Publication [7] studies the influence of the amount of air removed and fire size on the spread of smoke in indoor car parks. It describes test fires with a heat release rate of $200 \mathrm{~kW}$ to $4 \mathrm{MW}$, where the source of fire and smoke is a $3 \times 1.5 \times 0.5$ plate filled with water and hexanol. Despite the fact that liquid fuel (alcohol), not a vehicle, was the source of the fire, due to the suitable selection of fuel parameters, the smoke spread in the test indoor car park in a similar way as in the case of an actual car fire. These experiments were later recreated in the FDS software and presented in publication [8]. Further papers $[9,10]$ also describe the use of FDS to recreate previously conducted studies. [9] refers to actual fire studies of vehicles performed by BRE and presented in [3], including a fire of three adjacent cars in an indoor car park equipped with sprinklers. As for [10], it demonstrates the results of CFD simulations performed on the basis of the author's experiments at full scale - the ignition source being inside the passenger area or boot, or under the hood.

In the cases presented above, CFD simulations in individual car park models usually involved 1 to 3 passenger vehicles (or sources of fire imitating vehicles, [8] and [9]) in parking spaces. According to the BS 7346-7 standard [11] and the available technical knowledge, these cars constitute ignition sources with a heat release rate of ca. $4 \mathrm{MW}$ for a single car in an indoor car park with sprinklers or ca. $8 \mathrm{MW}$ for 2-3 adjacent occupied parking spaces in the absence of a sprinkler system. This assumes that the remaining parking spaces available at a given floor are left empty. Such simplifications are reasonable in scientific research focusing on the comparison of simulation results with experimental data. For the practical application of CFD simulations, it is more important to determine the impact of the civil structure's architecture on the flow of mass and heat in a fire and to answer the questions whether evacuation from the car park level will be undisrupted and whether the safety 
CFD istotniejsze jest określenie wpływu architektury obiektu na przepływ masy i ciepła w warunkach pożaru i odpowiedź na pytanie, czy ewakuacja z poziomu parkingu może przebiegać w sposób niezakłócony, oraz czy zapewnione jest bezpieczeństwo ekip ratowniczych $w$ trakcie prowadzenia działań ratowniczo-gaśniczych.

\section{Modelowanie numeryczne zapełnionego garażu}

Generatory losowe znajdują zastosowanie w tworzeniu scenariuszy analiz numerycznych na potrzeby inżynierii bezpieczeństwa pożarowego. Pierwszym przykładem wartym przywołania może być tutaj publikacja [12], w której omówiono wykorzystanie tej metody (przez autorów pracy nazywanej jako metoda Monte Carlo) w scenariuszach ewakuacji osób z budynku. Kolejnym przykładem zastosowania analogicznego podejścia może być artykuł Tohira i Spearpointa [13]. Autorzy tej publikacjiużyli metody losowego doboru scenariusza do określenia, które z miejsc parkingowych zostaną zapełnione. Na podstawie $m$.in. danych statystycznych o pożarach samochodów osobowych w Nowej Zelandii naukowcy oszacowali uśrednione zakresy mocy pożarów samochodów w zależności od klasy pojazdu (podział na klasy względem wagi aut). Natomiast głównym celem ich badań było określenie maksymalnej wygenerowanej mocy pożaru na podstawie wyznaczonego prawdopodobieństwa powstania pożaru różnej liczby pojazdów. W dokumencie na przykładowym scenariuszu zaprezentowano wyniki dla pożarów od 1 do 64 pojazdów osobowych i oszacowano ryzyka wystąpienia tego typu zdarzeń losowych. Podobną metodę służącą do określenia zajętości poszczególnych miejsc parkingowych zastosowano w niniejszej pracy badawczej.

Na potrzeby symulacji CFD opracowano w języku Visual Basic program komputerowy "GENERATOR ZAJĘTOŚCI MIEJSC POSTOJOWYCH". Wykorzystano do tego dane statystyczne dotyczące zarejestrowanych w 2015 r pojazdów w Unii Europejskiej oraz te pochodzące z dokumentu [14]. Program pozwala na wylosowanie 1 z 3 typów pojazdów: model A, B lub C (ryc. 1), które mogą zajmować określone stanowisko postojowe. Dzięki tym materiałom ustalono udział procentowy pojazdów danego typu przy zajmowaniu konkretnych miejsc postojowych w garażu. W niniejszej pracy dokonano ujednolicenia poszczególnych grup pojazdów, proponując podział tylko na 3 kategorie samochodów: małe, średnie i duże (tabela 1 i ryc. 1). Zastosowane uproszczenie wynika z faktu, iż w publikacji [14] wyodrębniono 9 podstawowych segmentów pojazdów (podobnie jak w [15]), natomiast różnice pomiędzy kształtem i wymiarami samochodów dla tylu zdefiniowanych klas są niewielkie. Wobec tego przyjęto, że rozbieżności te mają pomijalny wpływ na wyniki obliczeń numerycznych.

Ostateczna liczba analizowanych scenariuszy stanowiła kompromis pomiędzy możliwościami obliczeniowymi dostępnymi dla autorów a potrzebą analizy jak największej liczby skrajnych przypadków zagospodarowania miejsc postojowych. Liczba scenariuszy została zatem dobrana arbitralnie, co nie umniejsza możliwości oceny różnic pomiędzy przeprowadzonymi analizami. Ograniczenia związane z doborem scenariuszy zostały uwzględnione przy formułowaniu wniosków z pracy. of rescue teams deployed to conduct firefighting and rescue operations will be maintained.

\section{Numerical modelling of a full car park}

Random generators find application in developing numerical analysis scenarios for the purposes of fire safety engineering. The first notable example is publication [12], which describes the use of this method (to which its authors refer as the Monte Carlo method) in evacuation scenarios for people present in the building. The paper by Tohir and Spearpoint is an example of a similar approach [13]. Its authors used the random scenario selection method to determine which of the parking spaces will be occupied. On the basis of, i.a., statistical data on passenger car fires in New Zealand, scientists estimated the average fire size ranges for cars depending on segment (segmentation by car weight). The main objective of the research was to determine the maximum generated fire size (heat release rate) on the basis of the identified probability of the occurrence of a fire of various numbers of vehicles. The document explores an example scenario with results for fires of 1 to 64 passenger cars and estimates the risks of such random incidents. A similar method to determine the occupancy of individual parking spaces was used in this study.

For the purposes of CFD simulation a computer program called "PARKING SPACE OCCUPANCY GENERATOR" was written in Visual Basic. It uses statistical data on vehicles registered in 2015 in the European Union and data from document [14]. The program randomly chooses one of three vehicle types: A, B or C (Fig. 1), to occupy each individual parking space. This data facilitated determining the percentage of cars of each type occupying specific parking spaces inside a car park. This paper simplifies the vehicle segments by suggesting a division into only 3 car segments: small, medium and large (Table 1 and Fig. 1). This simplification is due to the fact that while publication [14] lists 9 basic car segments (similarly as [15]), the differences in shape and dimensions for these segments are small. For this reason, it was assumed that these differences have negligible impact on the results of numerical calculations.

The final number of analysed scenarios was a compromise between the computational power available to the authors and the need to analyse as large a number of extreme cases of parking space occupancy as possible. As a result, the number of scenarios was selected in an arbitrary manner, which does not, however, affect the possibility of analysing the differences between the performed analyses. The limitations connected with the choice of scenarios were taken into account in developing conclusions. 
Tabela 1. Udział procentowy poszczególnych klas pojazdów zastosowanych w badaniu i zarejestrowanych w UE w $2015 \mathrm{r}$. Table 1. The percentage contribution of different car types used in the research and registered in the EU in 2015

\begin{tabular}{lcc}
\hline Udziały danej klasy pojazdów zastosowanych do obliczeń numerycznych / The percentage of a given segment of vehicles used for numerical calculations \\
\hline & $\begin{array}{c}\text { Tdział procentowy / szansa wylosowania pojazdu z danego segmentu } \\
\text { / Percentage / probability of random occurrence by segment }\end{array}$ & Rodzaj pojazdu / Car type \\
\hline Model A & $32 \%$ & Opel Corsa \\
\hline Model B & $30 \%$ & Ford Escort \\
\hline Model C & $33 \%$ & Audi Q7 \\
\hline
\end{tabular}

Źródło: Opracowanie własne.

Source: Own elaboration.

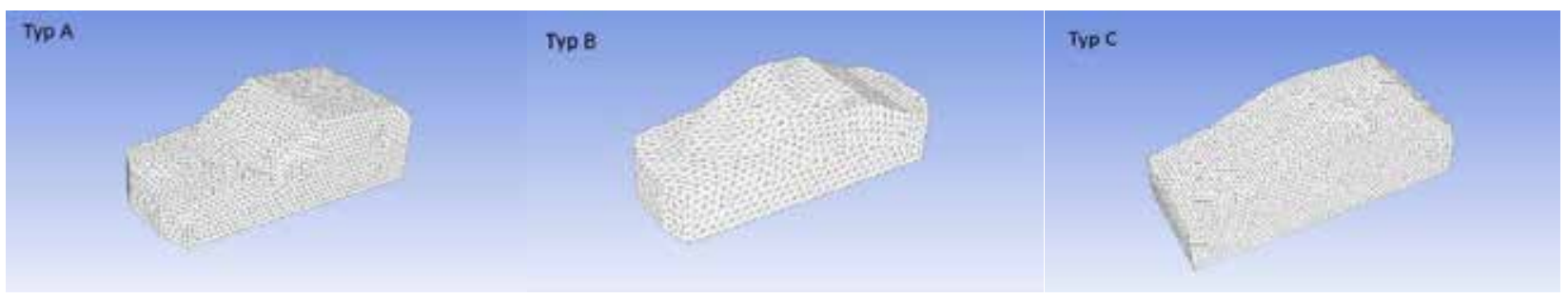

Rycina 1. Modele pojazdów typu A, B i C-segment małych, średnich i dużych samochodów

Figure 1. A, B and C car models - small, medium and large cars

Źródło: Opracowanie własne.

Source: Own elaboration.

Na rycinie nr 2 przedstawiono natomiast modele garaży, na podstawie których wykonano obliczenia numeryczne.
Figure 2 presents the car park models used for performing numerical calculations. a)

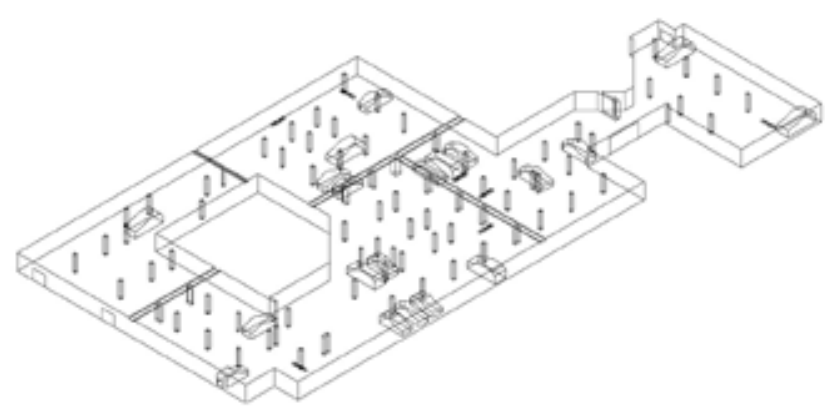

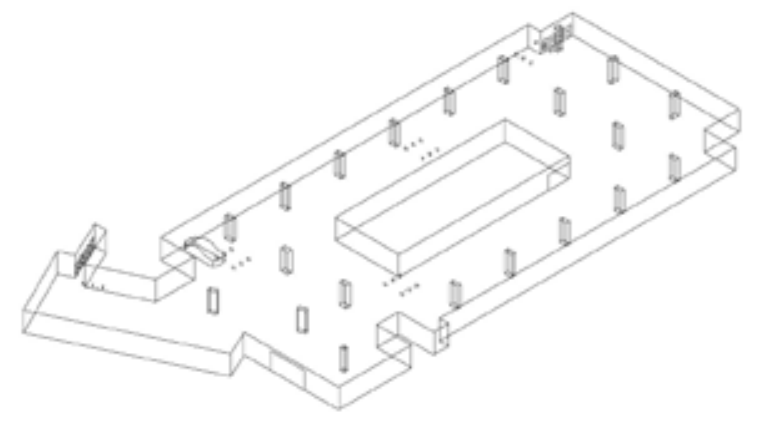

Rycina 2. Modele garaży opracowane na potrzeby obliczeń numerycznych Figure 2. Car park models created for the purposes of numerical calculations Źródło: Opracowanie własne.

Source: Own elaboration.

\section{Założenia dotyczące obliczeń numerycznych}

\section{Założenia dla systemów wentylacji pożarowej}

Obydwa garaże posiadają powierzchnię dużo mniejszą niż $5000 \mathrm{~m}^{2}$ (tabela 2), dlatego stanowią jedną strefę pożarową zgodnie z [16]. W przypadku garażu nr 1 zaprojektowany został system wentylacji mechanicznej oddymiającej wspomagany siedmioma wentylatorami strumieniowymi o sile ciągu $55 \mathrm{~N}$ każdy. Do usunięcia dymu i gorących gazów pożarowych

\section{Assumptions for numerical calculations}

\section{Assumptions for fire ventilation systems}

Both indoor car parks have areas much smaller than $5,000 \mathrm{~m}^{2}$ (Table 2), which is why they constitute a single fire compartment according to [16]. Car park No. 1 features a mechanical smoke exhaust ventilation system assisted by seven jet ventilators with a thrust of $55 \mathrm{~N}$ each. Two exhaust ducts powered by fire ventilators with flow rates of $80,000 \mathrm{~m}^{3} / \mathrm{h}$ each 
służą dwa szachty wyciągowe obsługiwane przez wentylatory pożarowe o wydatkach odpowiednio po $80000 \mathrm{~m}^{3} / \mathrm{h}$ na szacht. Lokalizację szachtów wyciągowych zaznaczono na ryc. 3 kolorem czerwonym. W czasie pożaru powietrze świeże doprowadzane jest mechanicznie poprzez szacht nawiewny (wydatek $30000 \mathrm{~m}^{3} / \mathrm{h}$ ) i grawitacyjnie poprzez otwartą bramę garażową (punkty nawiewne oznaczono na ryc. 7 kolorem niebieskim). W celu uproszczenia analiz przyjęto, że garaż o powierzchni $2835 \mathrm{~m}^{2}$ stanowi jedną strefę dymową. Pożar w scenariuszach dla garażu nr 1 został zainicjowany na stanowisku nr 32. Opis pożaru wykorzystanego $\mathrm{w}$ analizach przedstawiono $\mathrm{w}$ dalszej części artykułu. were used to remove smoke and hot fire gases. Exhaust duct locations are presented in Fig. 3 (in red). During a fire, fresh air is supplied mechanically through the air supply duct (flow rate: $30,000 \mathrm{~m}^{3} / \mathrm{h}$ ) and gravitationally (natural flow $-\mathrm{NF}$ ) through the open gate (inlet points indicated in blue in Fig. 7). To simplify analysis, it was assumed that an indoor car park with an area of $2,835 \mathrm{~m}^{2}$ constitutes a single smoke compartment. The fire in scenarios for Car park No. 1 was initiated in space No. 32. A description of the fire used in the analyses is presented further in this paper.

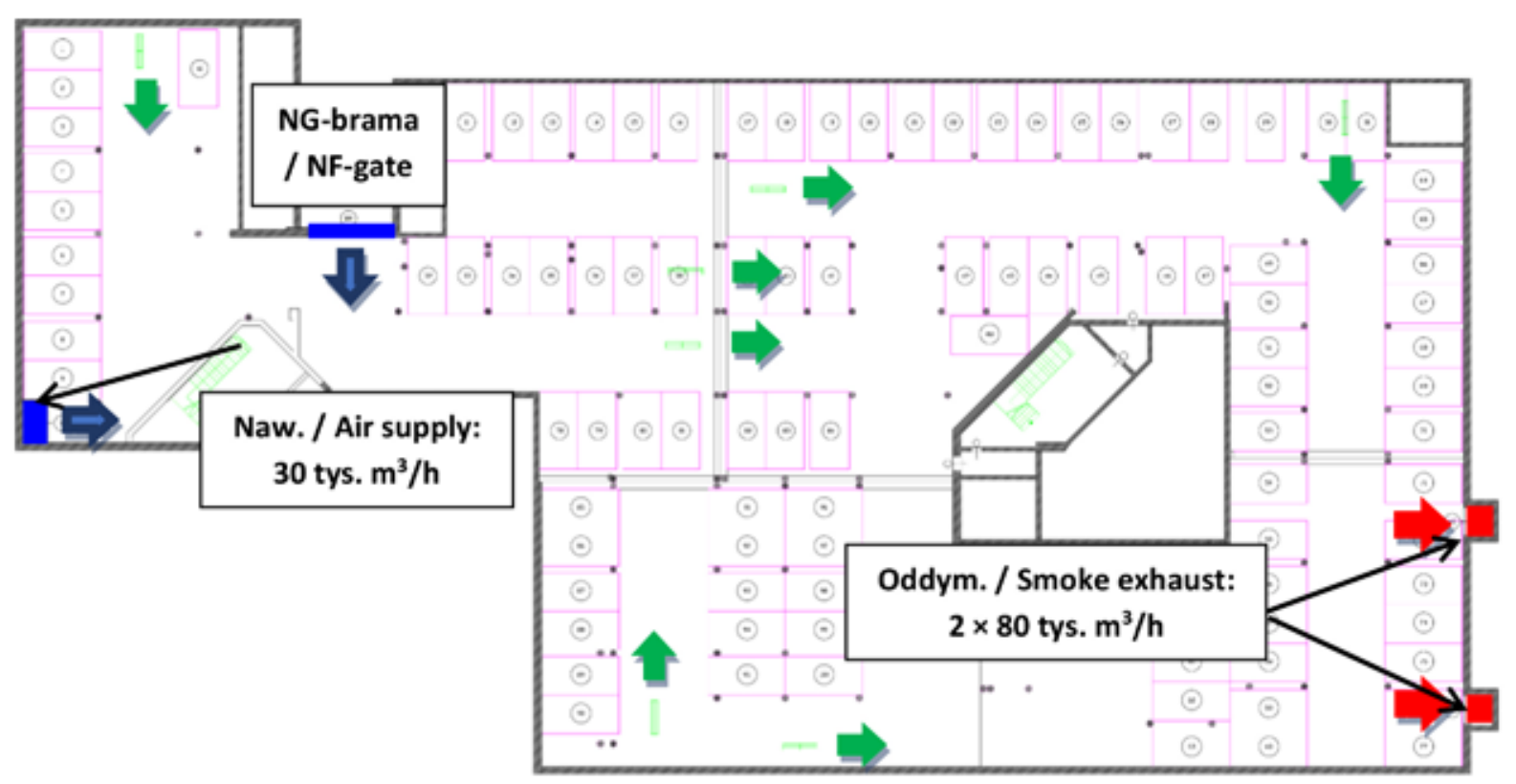

Rycina 3. Rzut instalacji oddymiającej garaż nr 1. Kolorem niebieskim oznaczono punkty nawiewne, kolorem czerwonym - szachty wyciągowe, kolorem zielonym wentylatory strumieniowe i kierunki ich pracy

Figure 3. Top view of the smoke exhaust system in Car park No. 1 Air inlet points are in blue, exhaust ducts are in red and jet ventilators and their directions are in green

Źródło: Opracowanie własne.

Source: Own elaboration.

W garażu nr 2 zaprojektowany został system wentylacji mechanicznej oddymiającej wspomagany 9 wentylatorami strumieniowymi o sile ciągu $55 \mathrm{~N}$ każdy. Założono, że wyciąg dymu i gorących gazów pożarowych odbywa się w nim za pomocą wentylatorów pożarowych o łącznym wydatku $160000 \mathrm{~m}^{3} / \mathrm{h}$ (szacht oddymiający oznaczono na ryc. 4 kolorem czerwonym). W czasie pożaru kompensacja powietrza świeżego następuje grawitacyjnie poprzez trzy punkty nawiewne: otwartą bramę garażową i dwie szachty zlokalizowane po przeciwległych krańcach budynku (punkty nawiewne oznaczono na ryc. 4 kolorem niebieskim). Garaż stanowi jedną strefę dymową. Pojazd będący źródłem ciepła i dymu to samochód na stanowisku nr 70 .
Car park No. 2 features a mechanical smoke exhaust ventilation system assisted by nine jet ventilators with a thrust of $55 \mathrm{~N}$ each. It was assumed that smoke and hot fire gases are being removed using fire ventilators with a total flow rate of $160000 \mathrm{~m}^{3} / \mathrm{h}$ (the smoke exhaust duct is presented in Fig. 4 (in red). During a fire, the compensation of fresh air occurs naturally through three inlet points - the open car park gate and two ducts located at the opposite ends of the buliding (inlet points are presented in Fig. 4 in blue). The indoor car park is a single smoke compartment. The vehicle being the source of heat and smoke is the car occupying parking space No. 70. 


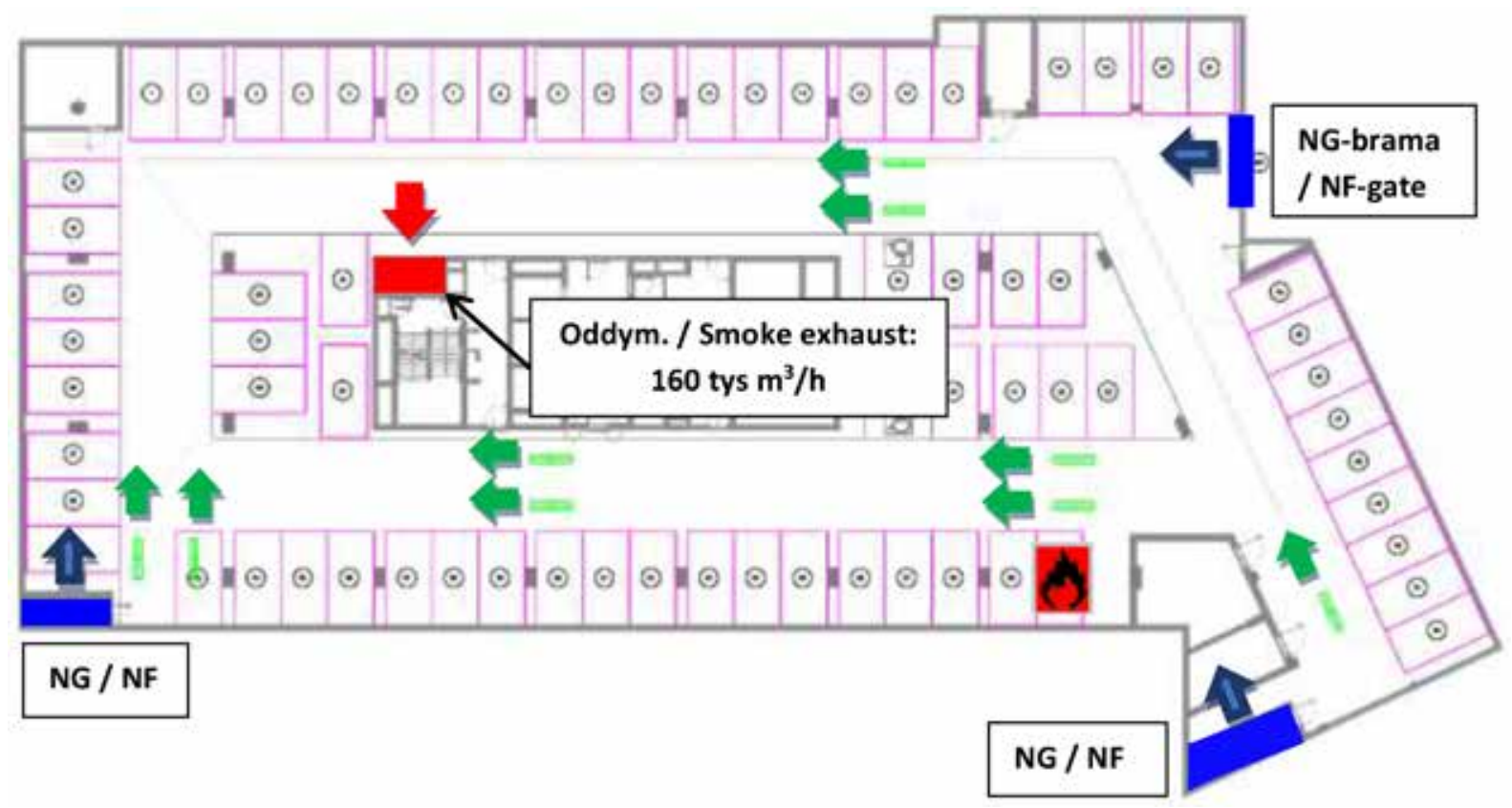

Rycina 4. Rzut instalacji oddymiającej garaż nr 2. Kolorem niebieskim oznaczono punkty nawiewne, kolorem czerwonym - szachty wyciągowe, kolorem zielonym - wentylatory strumieniowe i kierunki ich pracy

Figure 4. Top view of the smoke exhaust system in Car park No. 2. Air inlet points are in blue, exhaust ducts are in red and jet ventilators and their directions are in green

Źródło: Opracowanie własne.

Source: Own elaboration.

Dane geometryczne charakteryzujące poszczególne garaże zebrano w tabeli $\mathrm{nr} 2$.
Table 2 presents the geometrical data for the individual indoor car parks.

Tabela 2. Parametry geometryczne garaży

Table 2. Geometrical data of the car parks

\begin{tabular}{lcc} 
& Garaż nr 1 / Car park No. 1 & Garaż nr 2 / Car park No. 2 \\
\cline { 2 - 3 } Powierzchnia garażu / Car park area & $2858 \mathrm{~m}^{2} / 2,858 \mathrm{~m}^{2}$ & $1953 \mathrm{~m}^{2} / 1,953 \mathrm{~m}^{2}$ \\
\hline Wysokość garażu / Car park height & $2,75 \mathrm{~m} / 2.75 \mathrm{~m}$ & $2,9 \mathrm{~m} / 2.9 \mathrm{~m}$ \\
\hline llość szachtów oddymiających / Number of exhaust ducts & $2 \times 80 \mathrm{tys} . \mathrm{m}^{3} / \mathrm{h} / 2 \times 80,000 \mathrm{~m}^{3} / \mathrm{h}$ & $1 \times 160 \mathrm{tys} . \mathrm{m}^{3} / \mathrm{h} / 1 \times 160,000 \mathrm{~m} / \mathrm{h}$ \\
\hline Liczba miejsc postojowych / Number of parking spaces & 100 & 70 \\
\hline
\end{tabular}

Źródło: Opracowanie własne.

Source: Own elaboration.

Założenia przyjęte w obliczeniach numerycznych

Analizy przeprowadzono dla krzywej rozwoju pożaru TNO zawartej w normie NEN 6098:2012 [17] i krzywej at2 (o współczynniku a wynoszącym $0,0468 \mathrm{~kW} / \mathrm{s}^{2}$ ) dla źródła w postaci jednego samochodu osobowego. Zmniejszono natomiast moc pożaru do $4 \mathrm{MW}$ ze względu na wyposażenie obydwu garaży $w$ instalację tryskaczową. Zastosowano model objętościowego źródła ciepła i dymu, w którym generowane są ciepło oraz cząsteczki dymu. Zmiana parametrów w czasie została opisana funkcją użytkownika (tzw. UDF) [18].

Układ równań modelu obliczeniowej mechaniki płynów (CFD) wykorzystywany przez program ANSYS Fluent zawarto w jego dokumentacji technicznej [19]. Najważniejszymi podmodelami wykorzystanymi w obliczeniach były: model przepływu

\section{Assumptions for numerical calculations}

The analyses were performed for a TNO fire curve included in the NEN 6098:2012 standard [17] and at 2 curve (with the a coefficient of $0.0468 \mathrm{~kW} / \mathrm{s}^{2}$ ) for an ignition source of one passenger car. However, the heat release rate was reduced to $4 \mathrm{MW}$ due to both car parks being equipped with a sprinkler system. The volumetric heat and smoke source model, involving the generation of heat and smoke particles, was used. The change of parameters in time was described using a user-defined function (UDF) [18].

The system of equations of a computational fluid dynamics (CFD) model used by ANSYS Fluent software is provided in its technical documentation [19]. The most important submodels used in the calculations were the Realizable $k-\varepsilon$ turbu- 
turbulentnego typu Realizable $\mathrm{k}-\varepsilon$, uproszczony model promieniowania typu P1 oraz model transportu składników mieszaniny typu species transport. Szerszy opis metody obliczeniowej mechaniki płynów (CFD) oraz poszczególnych modeli fizycznych wykorzystywanych w niniejszej pracy przedstawiono w publikacji [20] poświęconej modelowaniu numerycznemu pożarów w garażach zamkniętych.

Na potrzeby rozwiązania transportu dymu przyjęto, że dym posiada te same właściwości fizyczne co powietrze [20]. Cząsteczki dymu generowane były z intensywnością wynikająca z chwilowej mocy pożaru, efektywnego ciepła spalania $(25,00$ $\mathrm{MJ} / \mathrm{kg}$ ) oraz współczynnika generacji sadzy $(0,1 \mathrm{~kg} / \mathrm{kg})$. Zmienność mocy pożaru w czasie przedstawiono na ryc. 5. Parametr uśrednionego efektywnego ciepła spalania przyjmowano w oparciu o [20] oraz [21], podczas gdy współczynnik generacji sadzy w oparciu o [22]. Podsumowanie założeń przyjętych w obliczeniach przedstawiono $w$ tabeli $n r 3$. Zainicjowany pożar rozwijał się według krzywych przedstawionych na ryc. 5 . lent model, the simplified P-1 radiation model and the mixture fraction transport model (species transport). A more extensive description of the computational fluid dynamics (CFD) method and the specific physical models used in this work is presented in publication [20] dedicated to the numerical modelling of fires in enclosed (indoor) car parks.

For the purposes of the smoke transport solution it was assumed that smoke has the same physical properties as air [20]. The smoke particles were generated with an intensity resulting from the transient heat release rate, the effective heat of combustion $(25.00 \mathrm{MJ} / \mathrm{kg})$ and soot yield $(0.1 \mathrm{~kg} / \mathrm{kg})$. The change of heat release rate over time is presented in Fig. 5 . The averaged effective heat of combustion parameter was adopted on the basis of [20] and [21] and the soot yield value was based on [22]. Table 3 presents a summary of the assumptions adopted in the calculations. The initiated fire developed according to the curves presented in Fig. 5.

Tabela 3. Parametry i modele obliczeń zastosowane w symulacjach

Table 3. The calculation parameters and models used in the simulations

\begin{tabular}{lc}
\hline & Modele matematyczne [19, 20] / Mathematical models [19, 20] \\
\hline Model turbulencji / Turbulence model & Realizable k-ع \\
\hline Model promieniowania / Radiation model & $\mathrm{P1}$ \\
\hline Model wymiany ciepła / Heat exchange model & oparty o prawo Fouriera / based on Fourier's law \\
\hline $\begin{array}{l}\text { Model transportu składników mieszaniny / Mixture fraction } \\
\text { transport model }\end{array}$ & Species transport \\
\hline
\end{tabular}

\begin{tabular}{|c|c|}
\hline Model pożaru / Fire model & $\begin{array}{l}\text { Objętościowe źródło ciepła i dymu uwzględniające zmienność produkcji w czasie } \\
\text { / Volumetric heat and smoke source taking into account the variability of its production over time }\end{array}$ \\
\hline \multicolumn{2}{|c|}{ Warunki brzegowe i początkowe / Boundary and initial conditions } \\
\hline $\begin{array}{l}\text { Temp. otoczenia/nawiewu kompensacyjnego } \\
\text { / Ambient temperature/compensation inlet temperature }\end{array}$ & $20^{\circ} \mathrm{C}$ \\
\hline Temp. wewnątrz garaży / Temp inside car parks & $20^{\circ} \mathrm{C}$ \\
\hline $\begin{array}{l}\text { Wsp. przejmowania ciepła dla ścian } \\
\text { / Heat transfer coefficient for walls }\end{array}$ & $35,00 \mathrm{~W} / \mathrm{m}^{2} \mathrm{~K} / 35.00 \mathrm{~W} / \mathrm{m}^{2} \mathrm{~K}$ \\
\hline Maksymalna moc pożaru / Maximum heat release rate & 4 lub $6 \mathrm{MW}$ (wg ryc. 5) / 4 or $6 \mathrm{MW}$ (according to Fig. 5) \\
\hline $\begin{array}{l}\text { Efektywne ciepło spalania - na podstawie }[20,21] \\
\text { / Effective heat of combustion - based on }[20,21]\end{array}$ & $25,00 \mathrm{MJ} / \mathrm{kg} / 25.00 \mathrm{MJ} / \mathrm{kg}$ \\
\hline $\begin{array}{l}\text { Wsp. dymotwórczości "soot yield" na podstawie [22] } \\
\text { / Soot yield based on [22] }\end{array}$ & $0,1 \mathrm{~kg} / \mathrm{kg} / 0.1 \mathrm{~kg} / \mathrm{kg}$ \\
\hline Ściany wykonane z żelbetu / Reinforced concrete walls & $\begin{aligned} \rho & =2500 \mathrm{~kg} / \mathrm{m}^{3} ; \lambda=1,7 \mathrm{~W} / \mathrm{mK} ; \mathrm{c}=0,84 \mathrm{~kJ} / \mathrm{kgK} \\
/ \rho & =2,500 \mathrm{~kg} / \mathrm{m}^{3} ; \lambda=1.7 \mathrm{~W} / \mathrm{mK} ; \mathrm{c}=0.84 \mathrm{~kJ} / \mathrm{kgK}\end{aligned}$ \\
\hline
\end{tabular}

Źródło: Opracowanie własne.

Source: Own elaboration.

Wykonano również analizę wpływu siatki na wyniki obliczeń. Wykorzystano tetrahedralną siatkę niestrukturalną. Weryfikacja ta pozwoliła na wybranie optymalnych wartości gęstości siatki ze scenariusza B (tabela 4, z siatką z odległością od źródła pożaru wynoszącą $15 \mathrm{~cm}$ oraz siatką w obszarze poza źródłem - $60 \mathrm{~cm}$ ).

Analizowane obszary w garażach podzielono za pomocą niestrukturalnej tetrahedralnej siatki numerycznej na skończoną liczbę objętości kontrolnych. Podział siatki obliczeniowej na objętości wynosił, w zależności od modelu i scenariusza, od ok.
An analysis of the influence of the mesh on calculation results was also performed. A non-structural tetrahedral mesh was used. This verification allowed the selection of optimum mesh density values from scenario $B$ (Table 4 , mesh with $15 \mathrm{~cm}$ distance from the ignition source and mesh in the area outside the source $-60 \mathrm{~cm}$ ).

The analysed areas in indoor car parks were divided using a non-structural tetrahedral computational mesh into a finite number of control volumes. The division of the computational mesh into volumes resulted in 632,000 to 688,000 (car park 
632000 do 688000 (garaż nr 1) i od ok. 555000 do 598000 (garaż nr 2) elementów. W rejonach, w których spodziewano się występowania dużych gradientów badanych wielkości fizycznych (m.in. obszar sąsiadujący ze źródłem pożaru oraz wlotów i wylotów powietrza), dokonano zagęszczenia siatki numerycznej
No. 1) and from 555,000 to 598,000 (car park No. 2) elements, depending on the model and scenario. In areas where large gradients in the studied physical properties were expected (including the area adjacent to the ignition source and air inlets and outlets), the computational mesh was condensed.

Tabela 4. Analiza wrażliwości zastosowanych siatek na wyniki obliczeń

Table 4. An analysis of the sensitivity of the meshes to calculation results

\begin{tabular}{lcccc}
\hline $\begin{array}{c}\text { Oznaczenie } \\
\text { scenariusza } \\
\text { / Scenario }\end{array}$ & $\begin{array}{c}\text { Przy źródle ciepła } \\
\text { / Near heat source } \\
{[\mathbf{c m}]}\end{array}$ & $\begin{array}{c}\text { Obszar zewnętrzny } \\
\text { / External area } \\
{[\mathbf{c m}]}\end{array}$ & $\begin{array}{c}\text { Maksymalna masowa koncentracja dymu } \\
\text { / Maximum mass concentration of smoke } \\
{\left[\mathbf{g} / \mathbf{m}^{3}\right]}\end{array}$ & $\begin{array}{c}\text { Maksymalna temperatura wypływającego dymu } \\
\text { / Maximum temperature of outflowing smoke } \\
{\left[{ }^{\circ} \mathrm{C}\right]}\end{array}$ \\
\hline $\mathrm{A}$ & 15 & 50 & 0,696 & 297,12 \\
\hline $\mathrm{B}$ & 15 & 60 & 0,7 & 300,71 \\
\hline $\mathrm{C}$ & 15 & 70 & 0,701 & 301,87 \\
\hline $\mathrm{D}$ & 10 & 60 & 0,703 & 301,84 \\
\hline
\end{tabular}

Źródło: Opracowanie własne.

Source: Own elaboration.

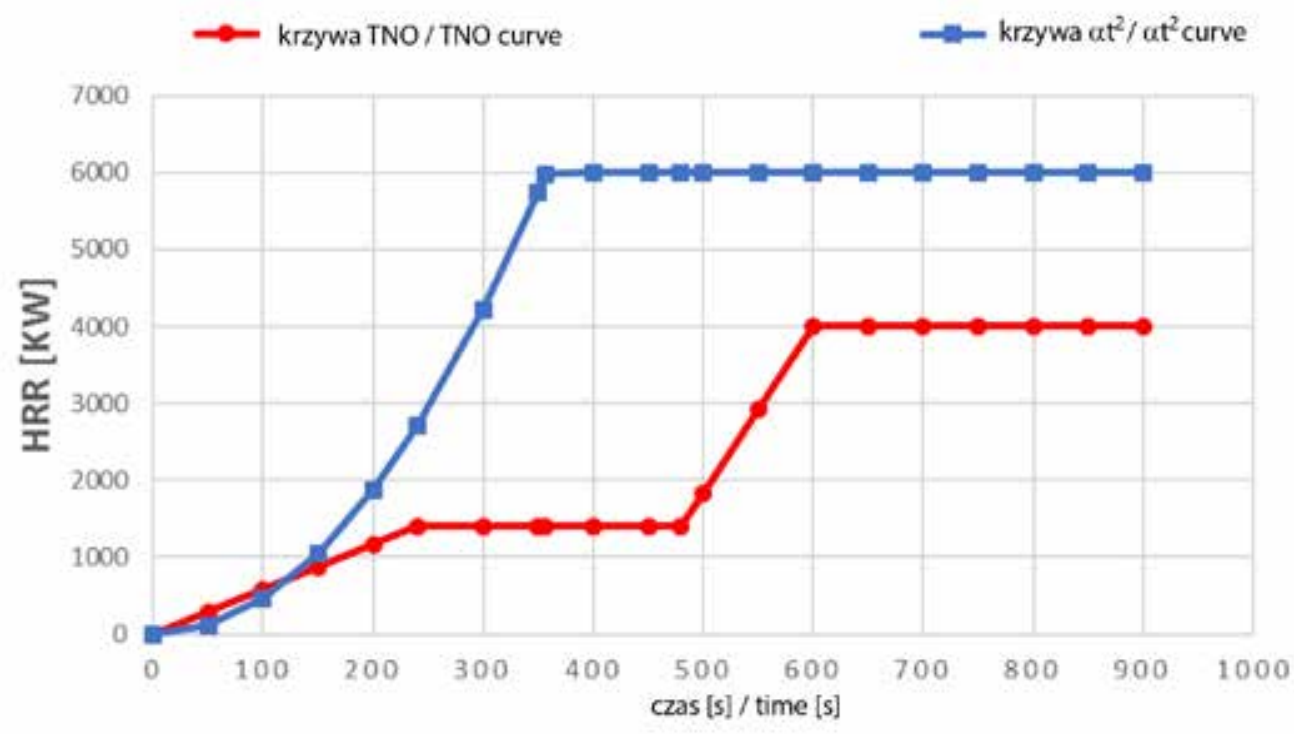

Rycina 5. Krzywe rozwoju pożaru zastosowane w obliczeniach numerycznych

Figure 5. Fire curves used in numerical calculations

Źródło: Opracowanie własne.

Source: Own elaboration.

\section{Analizy numeryczne i kryteria oceny}

Na potrzeby badań dla każdego z dwóch modeli garażu opracowano po jedenaście scenariuszy pożaru, w zależności od liczby i lokalizacji zajętych przez pojazdy (typ A, B lub C) miejsc postojowych. Wszystkie wyżej wymienione scenariusze przeliczono według krzywych TNO. Oprócz tego powtórzono obliczenia dla pożarów rozwijających się według krzywej at². Obydwie krzywe pożaru przedstawiono na ryc. 5. Informacje dotyczące zajętości miejsc parkingowych przez różną liczbę

\section{Numerical Analyses and Assessment Criteria}

For the purposes of the study, eleven scenarios were developed for each of the two car park models, depending on the number and location of the parking spaces occupied by vehicles (type A, B or C). All of the abovementioned scenarios were calculated according to TNO curves. In addition, calculations for fires developing according to the $a^{2}{ }^{2}$ curve were repeated. Both fire curves are presented in Fig. 5. Table 5 presents information concerning the occupancy rate of parking spaces by type 
pojazdów poszczególnych typów przedstawiono w tabeli 5. Do zaprezentowania w niniejszej publikacji wybrano najbardziej reprezentatywne scenariusze spośród wszystkich serii obliczeń wykonanych dla poszczególnych garaży. Prezentowane wyniki (masowa koncentracja dymu oraz pola prędkości) dotyczą zajętości miejsc parkingowych w 0\%, 20\%, 40\%,60\%, 80\% i w całkowicie wypełnionym garażu dla serii obliczeń wg krzywej TNO i w $0 \%, 40 \%$ oraz w $100 \%$ dla serii obliczeń wg krzywej $\mathrm{at}^{2}$. Ocenę wyników symulacji dla poszczególnych scenariuszy zawężono do czasu zakończenia ewakuacji osób, czyli do okoto trzysetnej sekundy od momentu zainicjowania pożaru. Jako kryterium oceny przyjęto, że przewidywana masowa koncentracja dymu w czasie ewakuacji osób w przejściach i drogach ewakuacyjnych na wysokości 1,80 m powyżej posadzki nie powinna przekraczać $0,105 \mathrm{~g} / \mathrm{m}^{3}$, co odpowiada lokalnej widzialności znaków ewakuacyjnych świecących własnym światłem równej lub mniejszej niż $10 \mathrm{~m}$. W symulacjach o mocy pożaru zwiększonej do 4,2 MW (wg at ${ }^{2}$ dla trzysetnej sekundy) zmieniono zakres prezentowania wyników masowej koncentracji dymu na $0,00-0,40 \mathrm{~g} / \mathrm{m}^{3}$, aby można było zaobserwować różnice pomiędzy symulacjami. of vehicle. The most representative scenarios from all series of calculations performed for individual car parks were selected for presentation in this publication. The presented results (for the mass concentration of smoke and velocity field) concern the $0 \%, 20 \%, 40 \%, 60 \%, 80 \%$ and $100 \%$ occupancy rate of parking spaces for the series of calculations according to the TNO curve and $0 \%, 40 \%$ and $10 \%$ for the series of calculations according to the $a t^{2}$ curve. The assessment of the simulation results for specific scenarios was narrowed down to the period until the evacuation of people is finished, i.e. until ca. 300 seconds after the moment of ignition. It was assumed as an assessment criterion that the expected mass concentration of smoke during the evacuation of people in passages and escape routes at a height of $1.80 \mathrm{~m}$ above floor level should exceed $0.105 \mathrm{~g} / \mathrm{m}^{3}$, which corresponds to a local visibility of escape sign luminaires equal to or lower than $10 \mathrm{~m}$. In simulations with a heat release rate increased to $4.2 \mathrm{MW}$ (according to $\mathrm{at}^{2}$ for the 300 th second) the range of presenting the results of the mass concentration of smoke was changed to $0.00-0.40 \mathrm{~g} / \mathrm{m}^{3}$ to facilitate the observation of differences between the simulations.

Tabela 5. Liczba miejsc postojowych $w$ danym garażu zajęta przez konkretny typ pojazdu A, B lub C

Table 5. The number of parking spaces in a given indoor car park occupied by a specific vehicle type (A, B or C)

\begin{tabular}{|c|c|c|c|c|c|c|}
\hline & \multirow{2}{*}{ Pożar / Fire } & \multirow{2}{*}{$\begin{array}{l}\text { Zajętość miejsc w \% } \\
\text { / Occupancy rate in \% }\end{array}$} & \multirow{2}{*}{$\begin{array}{c}\text { Nr symulacji } \\
\text { / Simulation No. }\end{array}$} & \multicolumn{3}{|c|}{ Liczba pojazdów / Number of vehicles } \\
\hline & & & & Typ A / A-segment & Typ B / B-segment & Typ C / C-segment \\
\hline \multirow{14}{*}{ 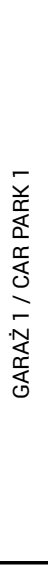 } & \multirow{11}{*}{ TNO } & 0 & 1 & 0 & 1 & 0 \\
\hline & & \multirow{2}{*}{20} & 2 & 8 & 4 & 2 \\
\hline & & & 3 & 1 & 7 & 6 \\
\hline & & \multirow{2}{*}{40} & 4 & 10 & 9 & 9 \\
\hline & & & 5 & 10 & 9 & 9 \\
\hline & & \multirow{2}{*}{60} & 6 & 7 & 17 & 18 \\
\hline & & & 7 & 8 & 15 & 19 \\
\hline & & \multirow{2}{*}{80} & 8 & 14 & 22 & 20 \\
\hline & & & 9 & 18 & 14 & 24 \\
\hline & & \multirow{2}{*}{100} & 10 & 16 & 23 & 31 \\
\hline & & & 11 & 12 & 29 & 29 \\
\hline & \multirow{3}{*}{$\mathrm{at}^{2}$} & 0 & 1 & 0 & 1 & 0 \\
\hline & & 40 & 2 & 10 & 9 & 9 \\
\hline & & 100 & 3 & 16 & 23 & 31 \\
\hline \multirow{14}{*}{ 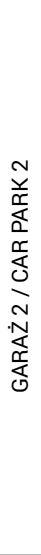 } & \multirow{11}{*}{ TNO } & 0 & 1 & 0 & 1 & 0 \\
\hline & & \multirow{2}{*}{20} & 2 & 11 & 2 & 7 \\
\hline & & & 3 & 5 & 8 & 7 \\
\hline & & \multirow{2}{*}{40} & 4 & 9 & 14 & 17 \\
\hline & & & 5 & 10 & 13 & 17 \\
\hline & & \multirow{2}{*}{60} & 6 & 20 & 19 & 21 \\
\hline & & & 7 & 22 & 18 & 20 \\
\hline & & \multirow{2}{*}{80} & 8 & 31 & 17 & 22 \\
\hline & & & 9 & 24 & 25 & 31 \\
\hline & & \multirow{2}{*}{100} & 10 & 30 & 34 & 36 \\
\hline & & & 11 & 33 & 23 & 44 \\
\hline & \multirow{3}{*}{$a t^{2}$} & 0 & 1 & 0 & 1 & 0 \\
\hline & & 40 & 2 & 9 & 14 & 17 \\
\hline & & 100 & 3 & 30 & 34 & 36 \\
\hline
\end{tabular}

Źródło: Opracowanie własne.

Source: Own elaboration. 


\section{Garaż 1}

\section{Rozwój pożaru wg krzywej TNO} (chwilowa moc pożaru w trzysetnej sekundzie: 1,4 MW)

Analiza wykonanych symulacji komputerowych dla garażu nr 1, pozwala zaobserwować znaczne różnice pomiędzy poszczególnymi scenariuszami związane z masową koncentracją dymu. Różnice te szczególnie dobrze widać w prawym górnym obszarze garażu (obszar 2 na ryc. 6). Różnica w ilości sadzy w powietrzu pomiędzy scenariuszem 1. i 10. może dochodzić nawet do ok. $0,085 \mathrm{~g} / \mathrm{m}^{3}$. Podobna sytuacja ma miejsce na obszarze wokół trzonu budynku (np. obszar 1, ryc. 22), gdzie ilość dymu jest znacznie większa w symulacji nr 10 niż w symulacji nr 1 o ok. $0,04 \mathrm{~g} / \mathrm{m}^{3}$. Wyniki pozostałych obliczeń dla różnych wariantów zapełnienia garażu pojazdami przedstawiono $w$ tabeli 6 .

W przypadku pola temperatur w 300. s różnice są na tyle małe pomiędzy wszystkimi scenariuszami, że nie mają one wpływu na pogorszenie lub wręcz uniemożliwienie prawidłowego przebiegu ewakuacji z zagrożonego obszaru.

W przypadku oceny pola prędkości można stwierdzić, że w garażu nr 1 powstało zawirowanie o średnicy znacząco przekraczającej wysokość garażu. Kształt wirów wytworzonych w wyniku działania systemu oddymiającego jest zbliżony we wszystkich zaprezentowanych scenariuszach. Jedyna różnica wynika z niewielkich zmian prędkości w poszczególnych fragmentach tego wiru. Natomiast istotnym faktem jest, że pomimo uformowania się wiru o tym samym kształcie we wszystkich symulacjach, samochody stanowią istotną przeszkodę na drodze strug powietrza i dymu. Wpływa to z kolei na dyssypację energii kinetycznej płynącego powietrza, co w rezultacie powoduje różnorodne zadymienie w odpowiadających sobie obszarach garażu.

\section{Car park 1}

\section{Fire development according to the TNO curve} (transient heat release rate in the 300th second: 1.4 MW)

An analysis of the computer simulations performed for car park No. 1 demonstrates significant differences between the individual scenarios in terms of the mass concentration of smoke. These differences are particularly noticeable in the top right area of the car park (Area 2 in Fig. 6). The diffreence in soot amount in air between scenarios 1 and 10 can be as high as $0.085 \mathrm{~g} / \mathrm{m}^{3}$. A similar situation is present in the area around the building's core (e.g. Area 1, Fig. 22), where the amount of smoke is much higher in simulation 10 than in simulation 1 (by ca. $0.04 \mathrm{~g} / \mathrm{m}^{3}$ ). Table 6 presents the results of the remaining calculations for various occupancy scenarios.

For the temperature field in the 300th second, the differences across all scenarios are so small that they cannot hinder or prevent the correct course of evacuation from the affected area.

For the velocity field, it can be stated that there was a turbulence in car park No. 1 with a diameter by far exceeding the height of the car park. The shape of the turbulences generated as a result of the operation of the smoke exhaust system is similar in all the presented scenarios. The only difference is due to slight velocity changes in the specific areas of the turbulence. However, it is important that even though the shape of the turbulence was the same in all simulations, cars constitute a significant obstacle to the flow of air and smoke. This, in turn, contributes to the dissipation of the kinetic energy of flowing air, which results in varied smoke accumulation in the corresponding car park areas.

Tabela 6. Przewidywana masowa koncentracja dymu na wysokości 1,8 m od poziomu posadzki [0,00-0,20 g/m³)] w trzysetnej sekundzie symulacji; Garaż 1

Table 6. The expected mass concentration of smoke at a height of $1.8 \mathrm{~m}$ from the floor level $\left.\left[0.00-0.20 \mathrm{~g} / \mathrm{m}^{3}\right)\right]$ in the 300 th second of the simulation; Car park No. 1

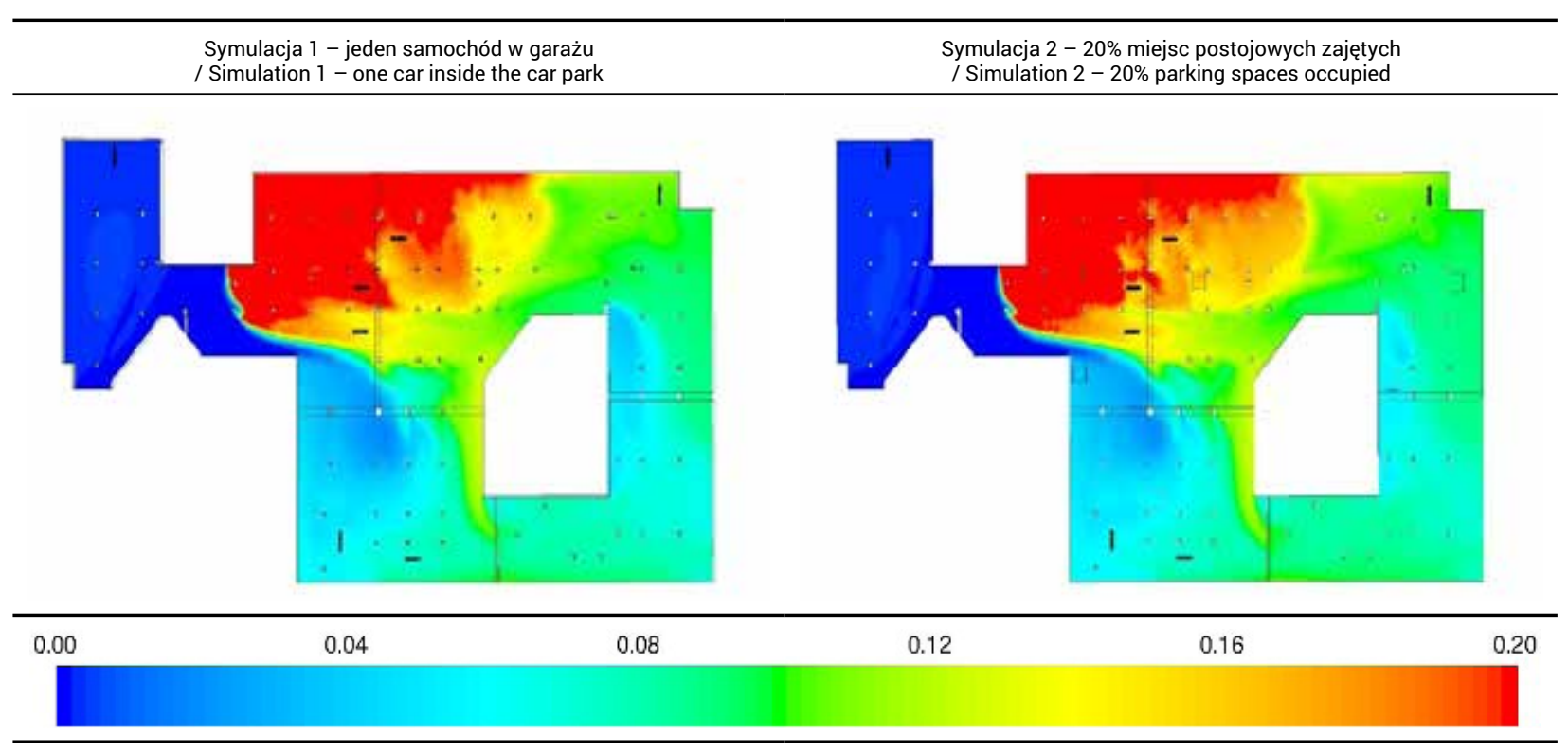




\section{INŻYNIERIA POŻAROWA}

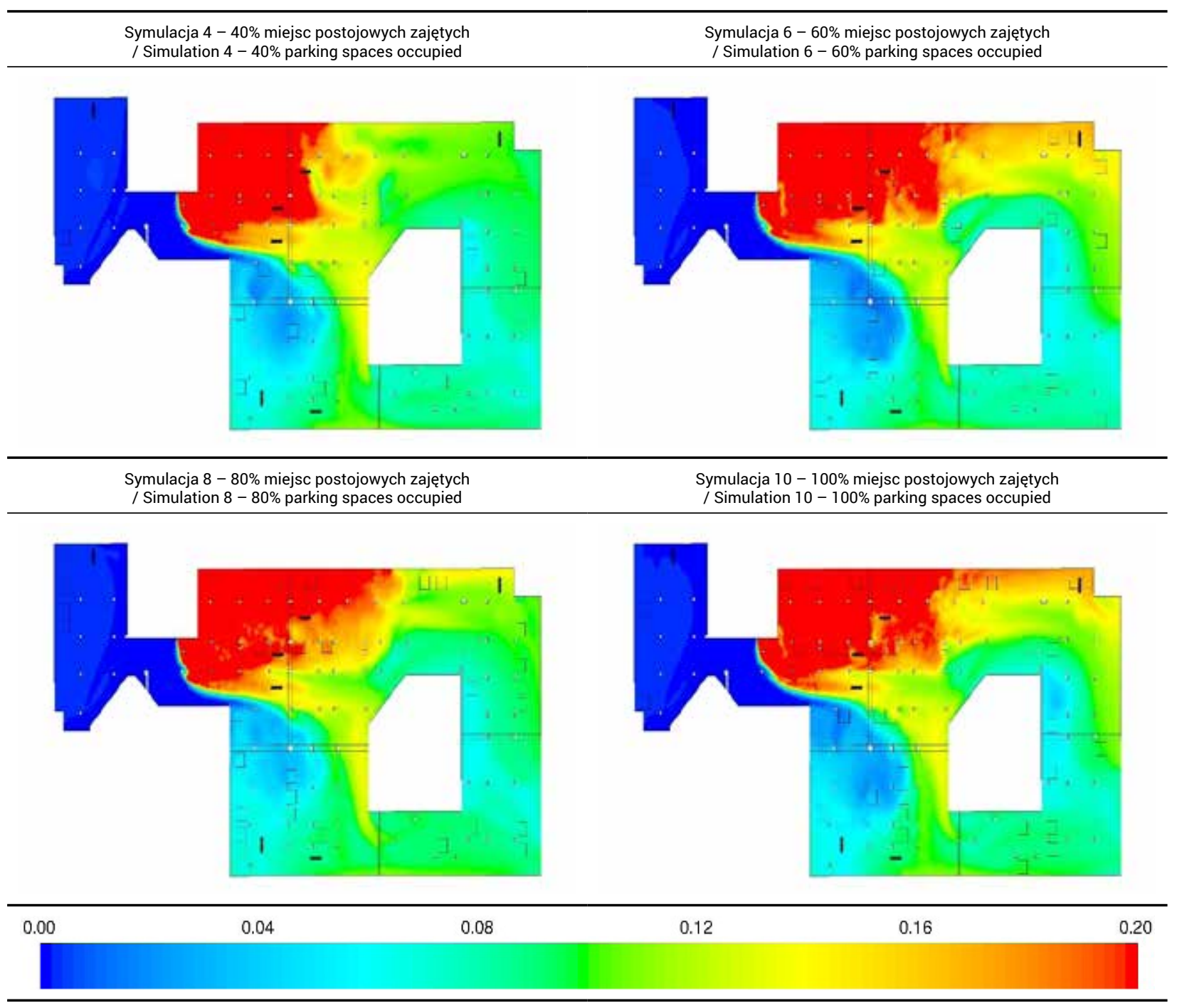

Źródło: Opracowanie własne.

Source: Own elaboration.

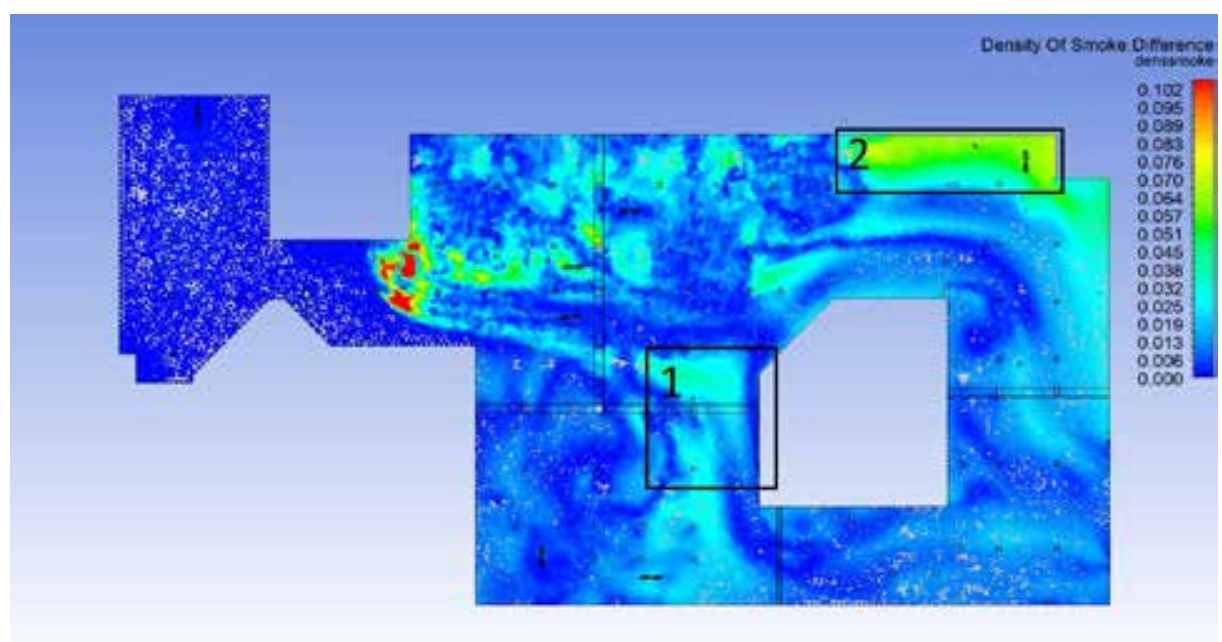

Rycina 6. Różnice w masowej koncentracji dymu [g/m³] pomiędzy symulacją nr 1 a $10 \mathrm{w}$ trzysetnej sekundzie symulacji

Figure 6. Differences in the mass concentration of smoke $\left[\mathrm{g} / \mathrm{m}^{3}\right]$ between simulations 1 and 10 in the 300 th second of the simulation Źródło: Opracowanie własne.

Source: Own elaboration. 
Tabela 7. Przewidywane pole prędkości na wysokości $1,8 \mathrm{~m}$ od posadzki [0-5 m/s] w trzysetnej sekundzie symulacji; Garaż 1

Table 7. The expected velocity field at a height of $1.8 \mathrm{~m}$ from the floor level $[0-0.5 \mathrm{~m} / \mathrm{s}]$ in the 300 th second of the simulation; Car park No. 1

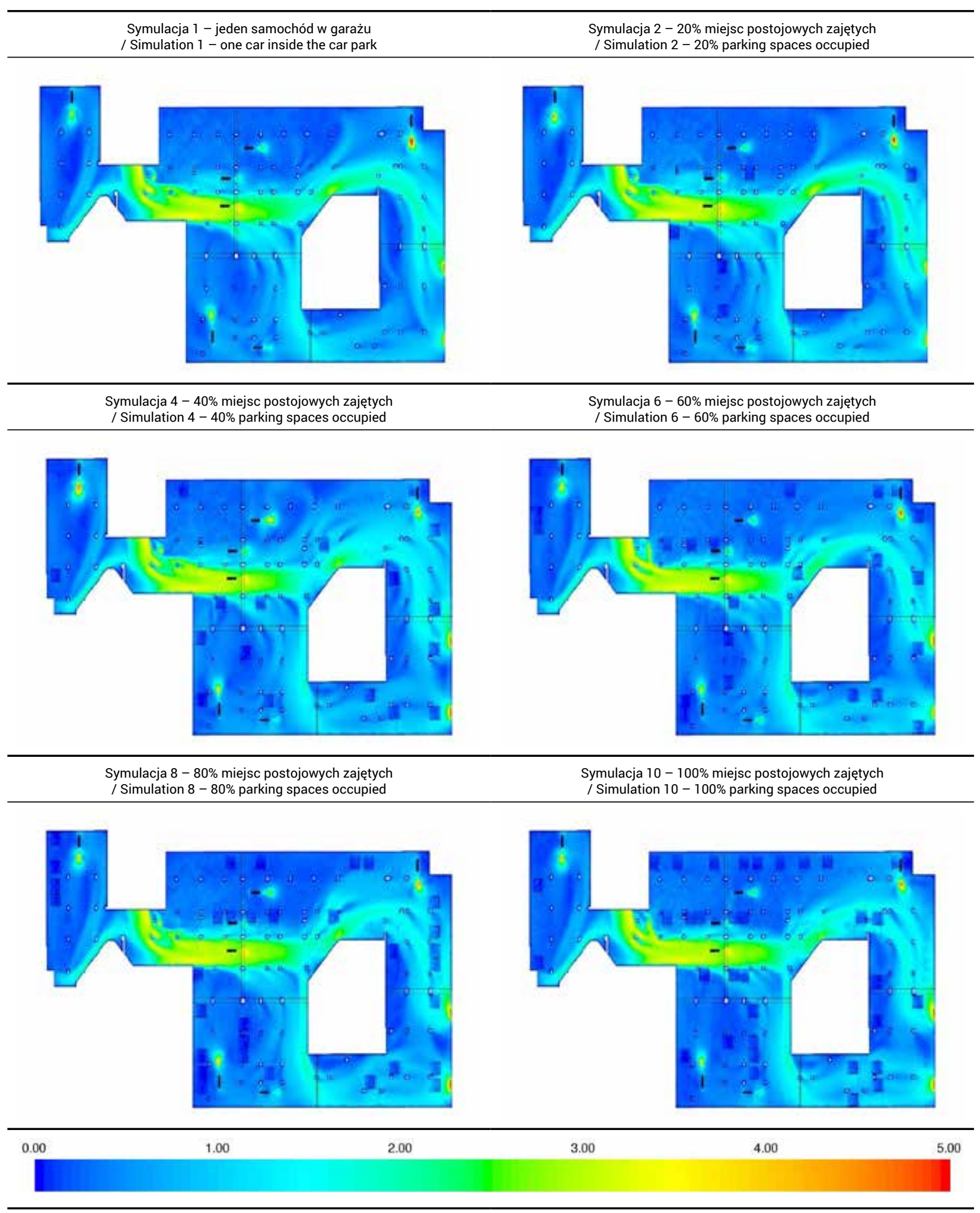

Źródło: Opracowanie własne.

Source: Own elaboration. 


\section{Rozwój pożaru wg krzywej at ${ }^{2}$ (chwilowa moc pożaru w trzysetnej sekundzie: 4,2 MW)}

W symulacji nr 3, w prawym dolnym rogu garażu, ilość wygenerowanego dymu podczas pożaru o mocy $4,2 \mathrm{MW}$ osiąga wartość w przedziale od 0,13 do $0,15 \mathrm{~g} / \mathrm{m}^{3}$. W symulacji $\mathrm{nr} 1$ odpowiadające temu miejscu parametry są znacznie niższe - ok. $0,11 \mathrm{~g} / \mathrm{m}^{3}$. Dodatkowo z analizy obliczeń $\mathrm{nr}$ 1, 2 i 3 przy zwiększonych zakresach masowej koncentracji dymu na płaszczyźnie wynikowej widać rozbieżności w prawym górnym rogu garażu. Różnica w ilości wygenerowanego dymu w tej lokalizacji może dochodzić do $0,07 \mathrm{~g} / \mathrm{m}^{3}$.

Pola temperatur podobnie jak pola prędkości na wysokości 1,8 m są do siebie zbliżone dla wszystkich trzech wykonanych symulacji.

\section{Fire development according to the $a^{2}$ curve (transient heat release rate in the 300 th second: \\ 4.2 MW)}

For simulation 3 , in the lower right corner of the car park, the amount of generated smoke during a fire with a heat release rate of $4.2 \mathrm{MW}$ reaches a value between 0.13 and $0.15 \mathrm{~g} / \mathrm{m}^{3}$. For simulation 1, the parameters for the corresponding area are much lower - ca. $0.11 \mathrm{~g} / \mathrm{m}^{3}$. Furthermore, for the analysis of computations 1, 2 and 3 with elevated ranges of the mass concentration of smoke, the results plane shows differences in the upper right corner of the car park. The difference in the amount of smoke generated in this location can reach $0.07 \mathrm{~g} / \mathrm{m}^{3}$.

Like velocity fields, temperature fields at the height of $1.8 \mathrm{~m}$ are similar for all three simulations.

Tabela 8. Przewidywana masowa koncentracja dymu na wysokości $1,8 \mathrm{~m}$ od poziomu posadzki $\left.\left[0,00-0,40 \mathrm{~g} / \mathrm{m}^{3}\right)\right] \mathrm{w}$ trzysetnej sekundzie symulacji; Garaż 1

Table 8. The expected mass concentration of smoke at a height of $1.8 \mathrm{~m}$ from the floor level $\left.\left[0.00-0.40 \mathrm{~g} / \mathrm{m}^{3}\right)\right]$ in the 300 th second of the simulation; Car park No. 1

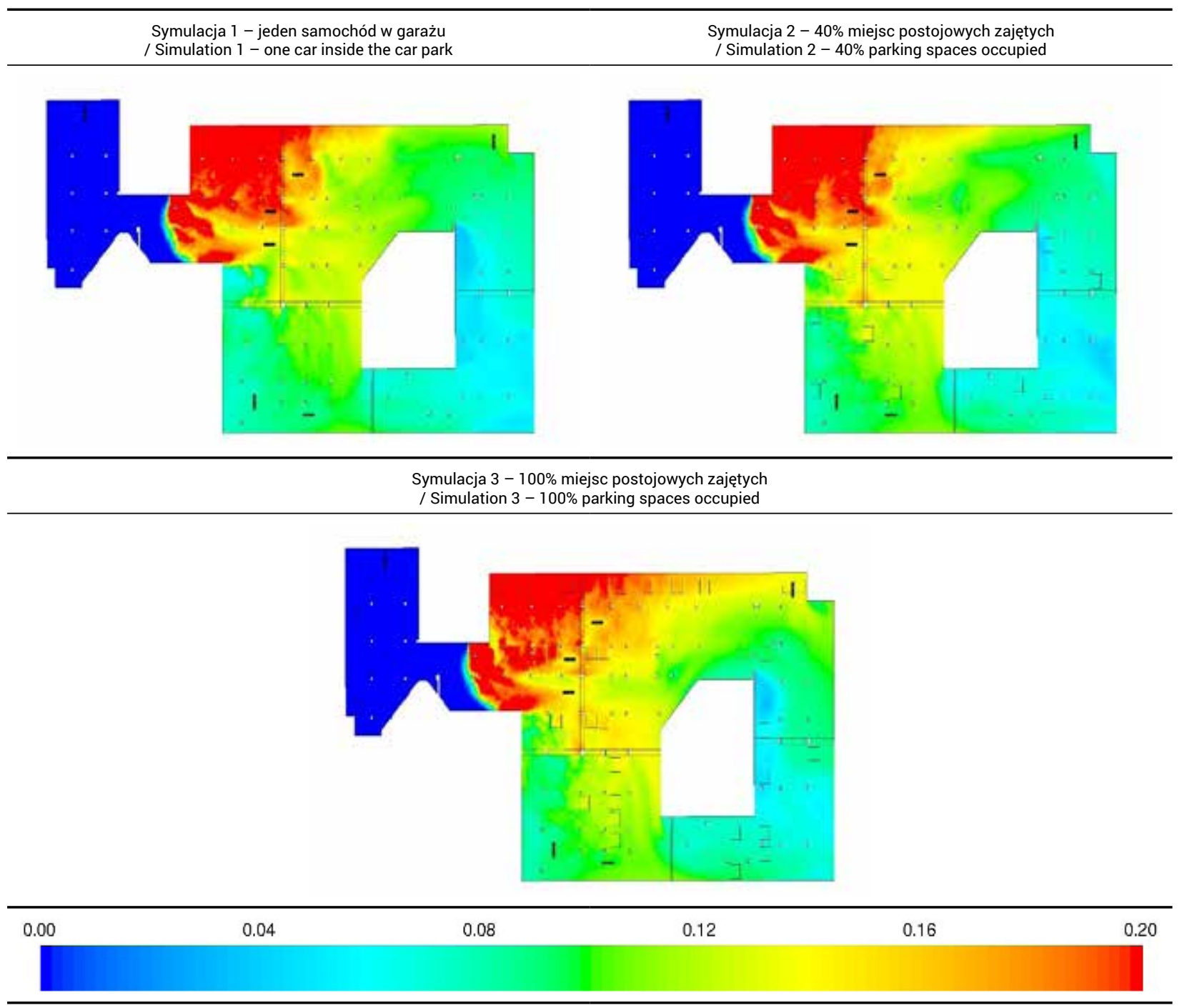

Źródło: Opracowanie własne.

Source: Own elaboration. 


\section{Garaż 2}

\section{Rozwój pożaru wg krzywej TNO (chwilowa moc pożaru w trzysetnej sekundzie: 1,4 MW)}

Masowa koncentracja dymu przyjmuje całkowicie różne wartości dla odpowiadających sobie obszarów w poszczególnych scenariuszach. Widać to dokładnie m.in. w lewej dolnej części garażu (obszar 1, ryc. 7) - jeśli porówna się ze sobą np. symulacje 1 i 10. Dla wariantu z jednym pojazdem ta część garażu jest całkowicie zadymiona. Rozbieżność tutaj dochodzi nawet do ok. $0,105 \mathrm{~g} / \mathrm{m}^{3}$. Podobne różnice można odnotować podczas porównywania obliczeń dla obszaru położonego w pobliżu trzonu budynku (obszary 2 i 4, ryc. 7), na obszarze 3 oraz obok prawego szachtu nawiewnego (obszar 5, ryc. 7). Natomiast wraz ze wzrostem liczby pojazdów w garażu w przestrzeniach nr 3 i 5 znacznie spada ilość dymu na ocenianym poziomie 1,8 $\mathrm{m}$.

W odniesieniu do pola temperatury można zaobserwować, że dla garażu z niezajętymi miejscami postojowymi uzyskane wartości tego parametru na wysokości 1,8 m od poziomu posadzki są wyższe w prawej części garażu, podczas gdy dla wypełnionego całkowicie pojazdami garażu temperatury są wyższe w dolnej części parkingu podziemnego.

Porównując pola prędkości przepływu mieszaniny dymu i powietrza na poziomie 1,8 m od posadzki, daje się zauważyć, że dla garaży wypełnionych pojazdami nie tworzy się wir wokół trzonu budynku, tak jak w symulacji nr 1 .

Dodatkowo można zauważyć, że w rozpatrywanych symulacjach pole prędkości przyjmuje inny kształt w obszarze pomiędzy bramą pożarową a kratą wyciągową (większe prędkości w tej części garażu uzyskiwane są dla symulacji nr 6, 8 i 10).

\section{Car park 2}

Fire development according to the TNO curve (transient heat release rate in the 300 th second: 1.4 MW)

The mass concentration of smoke assumes completely different values for the corresponding areas across different scenarios. This is clearly visible in e.g. the lower left part of the car park (area 1, Fig. 7) - when comparing simulations 1 and 10. For the variant with only one vehicle this part of the car park is completely engulfed by smoke. Here, the difference is up to even $0.105 \mathrm{~g} / \mathrm{m}^{3}$. Similar differences can be observed when comparing the calculations for the area located near the building's core (areas 2 and 4, Fig. 7), in area 3 and near the right air supply duct (area 5, Fig. 7). As the number of vehicles in the indoor car park increases the amount of smoke at the height of $1.8 \mathrm{~m}$ in areas 3 and 5 decreases significantly.

With regard to the temperature field, it can be observed that for the car park with no parking spaces occupied, the obtained values for this parameter at the height of $1.8 \mathrm{~m}$ from the floor level are higher in the right-hand part of the car park, while for the fully-occupied car park the temperatures are higher in its the lower part.

When comparing the velocity fields of the smoke and air mixture flow at the height of $1.8 \mathrm{~m}$ from the floor level, it is noticeable that for car parks occupied with vehicles no turbulence around the building's core is formed, such as in simulation 1 .

In addition, it should be noted that in the considered simulations the velocity field assumes a different shape in the area between the fire gate and the exhaust grille (higher speeds in this part of the car park are obtained for simulations 6,8 and 10).

Tabela 9. Przewidywana masowa koncentracja dymu na wysokości 1,8 m od poziomu posadzki [0,00-0,20 g/m³)] w trzysetnej sekundzie symulacji; Garaż 2

Table 9. The expected mass concentration of smoke at a height of $1.8 \mathrm{~m}$ from the floor level $\left.\left[0.00-0.20 \mathrm{~g} / \mathrm{m}^{3}\right)\right]$ in the 300 th second of the simulation; Car park No. 2

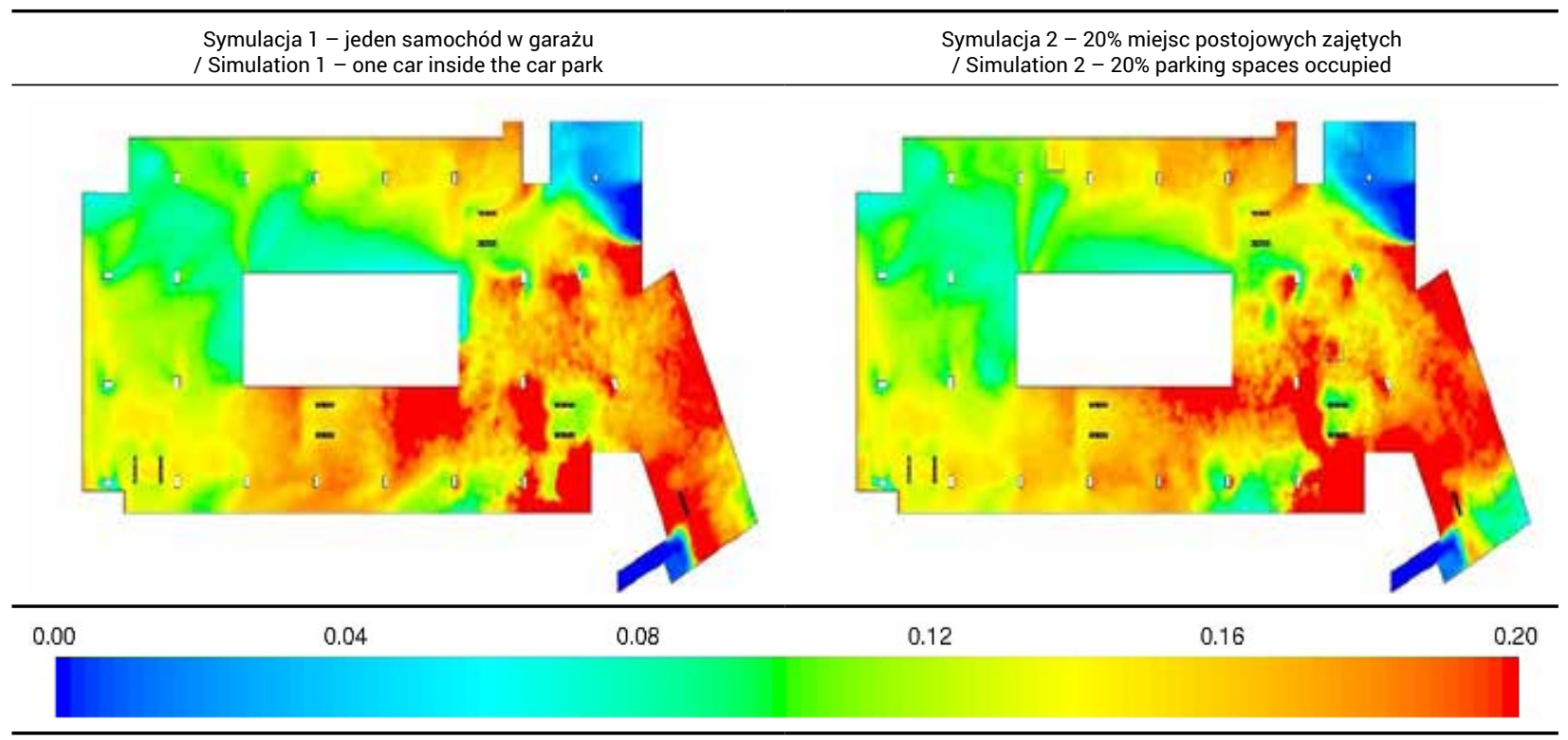




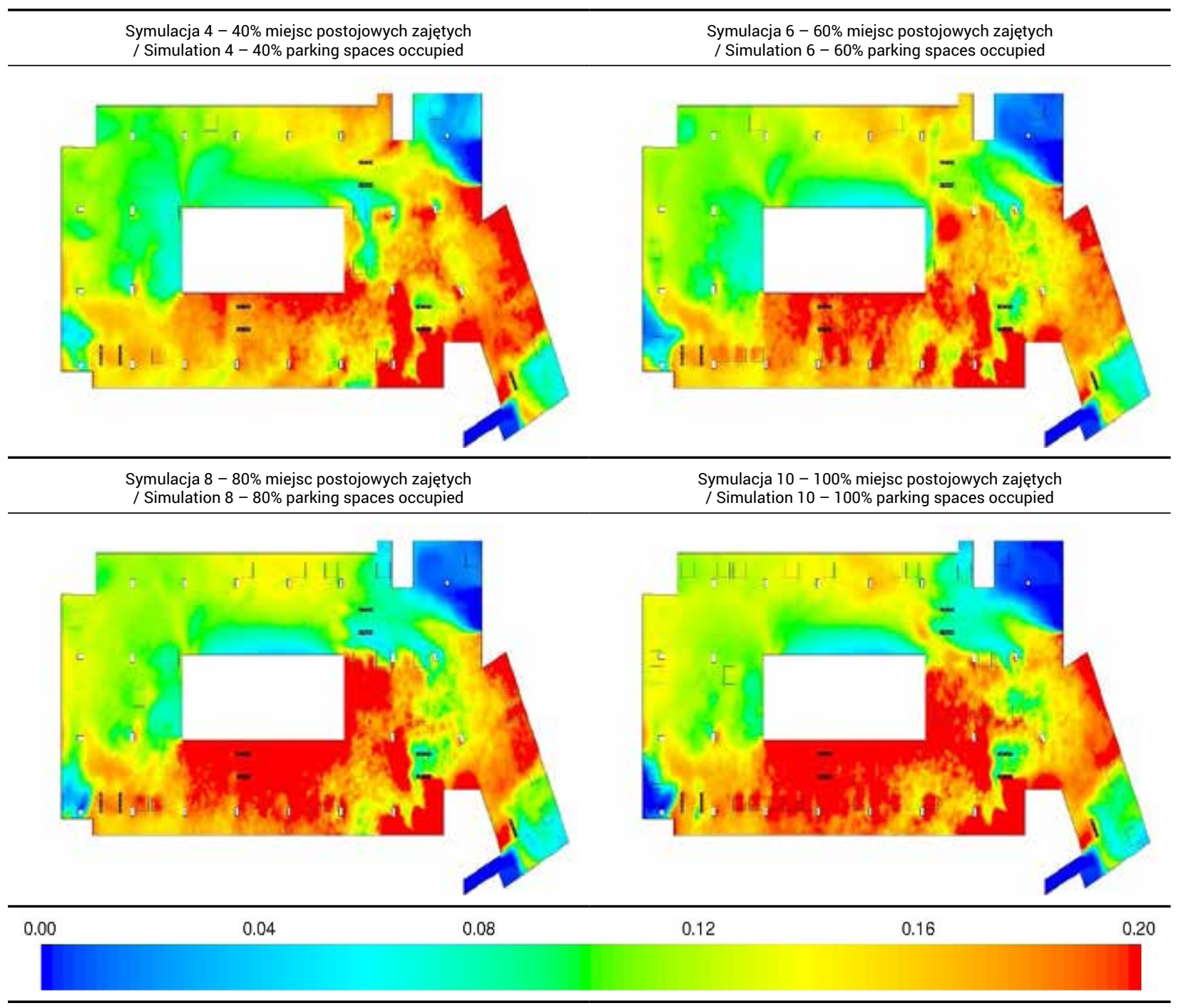

Źródło: Opracowanie własne.

Source: Own elaboration.

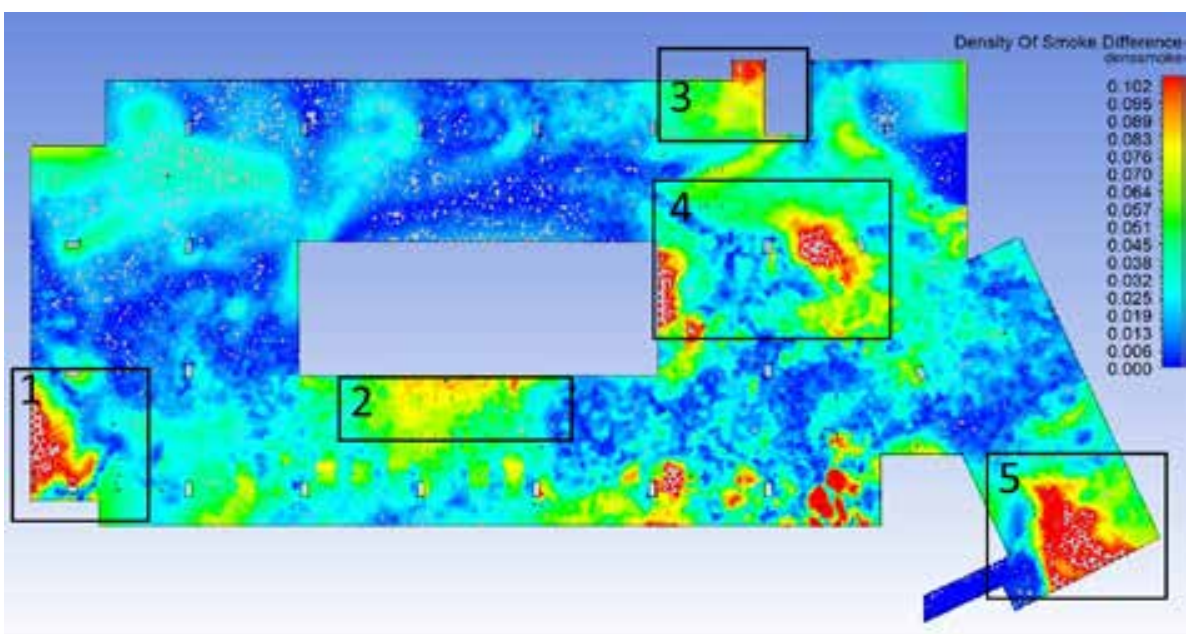

Rycina 7. Różnice w masowej koncentracji dymu $\left[\mathrm{g} / \mathrm{m}^{3}\right]$ pomiędzy symulacją $\mathrm{nr} 1$ a 10

Figure 7. Differences in the mass concentration of smoke $\left[\mathrm{g} / \mathrm{m}^{3}\right]$ between simulations 1 and 10

Żródło: Opracowanie własne.

Source: Own elaboration 
Tabela 10. Przewidywane pole prędkości na wysokości $1,8 \mathrm{~m}$ od posadzki [0-5 m/s] w trzysetnej sekundzie symulacji; Garaż 2

Table 10. The expected velocity field at a height of $1.8 \mathrm{~m}$ from the floor level $[0-0.5 \mathrm{~m} / \mathrm{s}]$ in the 300 th second of the simulation; Car park No. 2

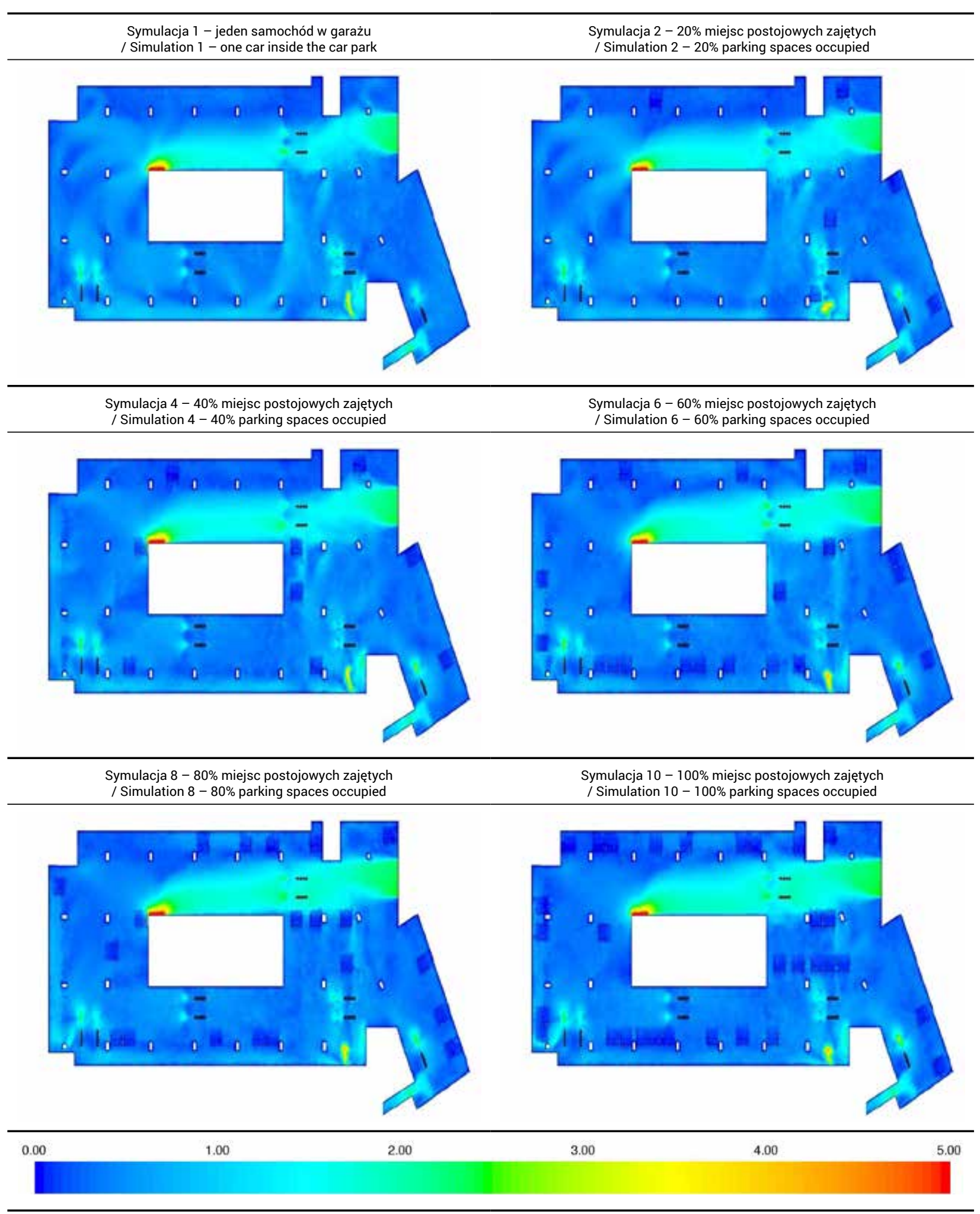

Źródło: Opracowanie własne.

Source: Own elaboration. 


\section{Rozwój pożaru wg krzywej at ${ }^{2}$} (chwilowa moc pożaru w trzysetnej sekundzie: 4,2 MW)

Różnice w wynikach między trzema obliczonymi symulacjami można zaobserwować w prawym górnym rogu garażu. Widać tam, że dla symulacji nr 3 wartość masowej koncentracji dymu waha się od 0,07 do $0,11 \mathrm{~g} / \mathrm{m}^{3}$. W analogicznym obszarze w symulacji $\mathrm{nr} 1$ koncentracja dymu wynosi w tym miejscu ok. $0,2 \mathrm{~g} / \mathrm{m}^{3}$. Oprócz tego, rozbieżności w wynikach pojawiają się zwłaszcza w okolicy trzonu - po lewej jego stronie oraz poniżej.

Dla pola temperatury różnice w wynikach można zauważyć w obszarze poniżej trzonu budynku - rozbieżności pomiędzy symulacjami nr 1 a 10 mogą dochodzić w tym miejscu nawet do ok. $40^{\circ} \mathrm{C}$.

\section{Fire development according to the $a^{2}$ curve (transient heat release rate in the 300 th second: 4.2 MW)}

The differences in results between the three computed simulations can be observed in the upper right corner of the car park. It can be seen that for simulation 3 the value of the mass concentration of smoke varies between 0.07 and $0.11 \mathrm{~g} / \mathrm{m}^{3}$. Within the same area in simulation 1 the concentration of smoke in this location is ca. $0.2 \mathrm{~g} / \mathrm{m}^{3}$. In addition, the differences in results appear especially near the building's core - to its left and below.

For the temperature field, the differences in results can be observed in the area below the building's core - the differences between simulations 1 and 10 might reach ca. $40^{\circ} \mathrm{C}$ in this location.

Tabela 11. Przewidywana masowa koncentracja dymu na wysokości $1,8 \mathrm{~m}$ od poziomu posadzki $\left.\left[0,00-0,40 \mathrm{~g} / \mathrm{m}^{3}\right)\right] \mathrm{w}$ trzysetnej sekundzie symulacji; Garaż 2

Table 11. The expected mass concentration of smoke at a height of $1.8 \mathrm{~m}$ from the floor level $\left.\left[0.00-0.40 \mathrm{~g} / \mathrm{m}^{3}\right)\right]$ in the 300 th second of the simulation; Car park No. 2

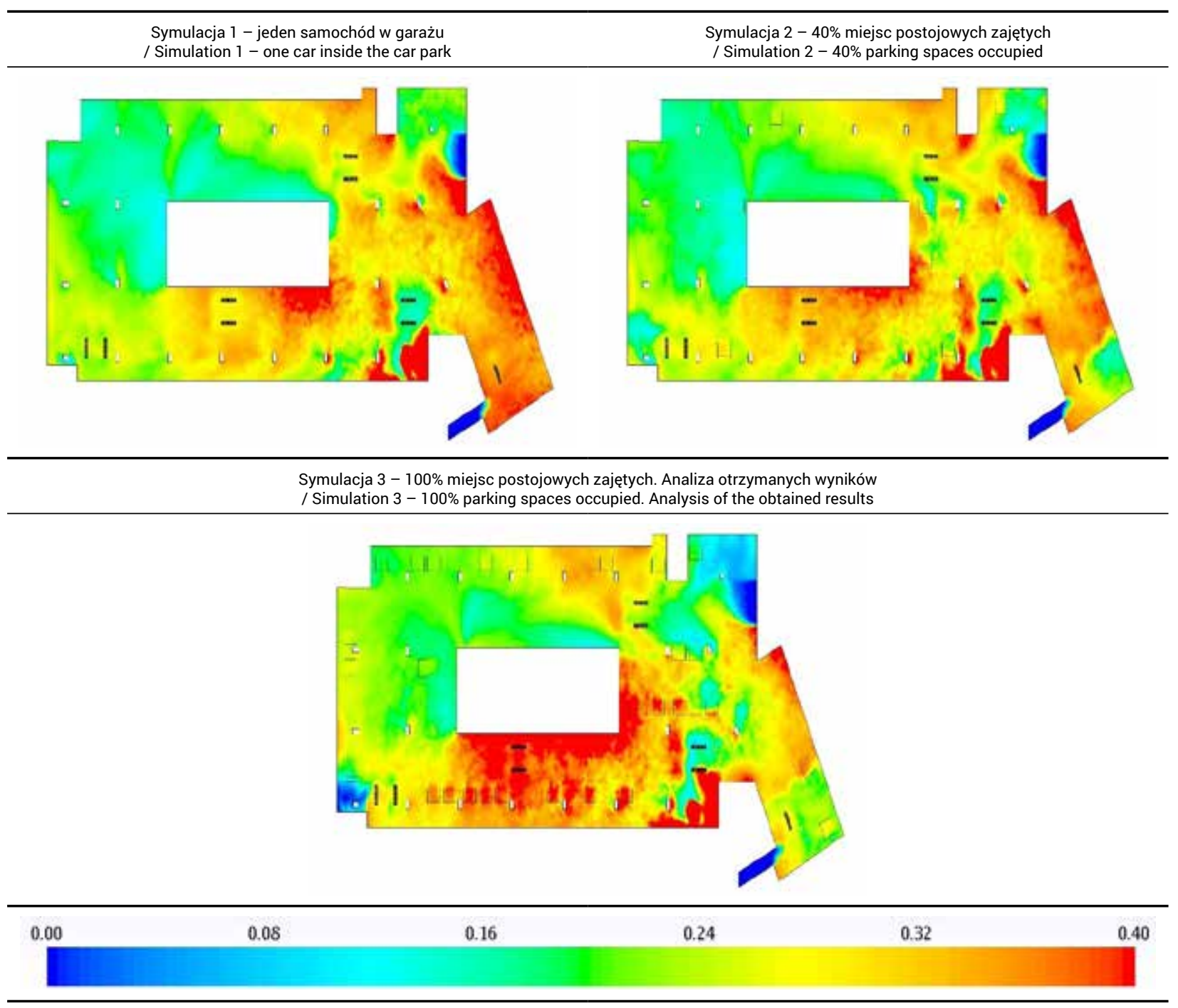

Źródło: Opracowanie własne.

Source: Own elaboration. 


\section{Wnioski}

W niniejszej pracy przeanalizowano wpływ zaparkowanych pojazdów na rozprzestrzenianie się dymu i gorących gazów pożarowych w garażu. W pracy przedstawiono dwa odmienne modele zamkniętych parkingów podziemnych z obliczeniami numerycznymi dla różnych mocy pożaru: 1,4 MW i 4,2 MW. Na podstawie analizy wykonanych symulacji można zauważyć, że wielkości powstałych zawirowań powietrza w garażu (których średnica znacząco przekracza wysokość garażu) i wysoka prędkość przepływu w tych zawirowaniach mają istotny wpływ na masową koncentrację dymu w analizowanym obszarze. W przypadku pola temperatur różnice pomiędzy symulacjami zakładającymi różny stopnień zajętości stanowisk parkingowych są w przeważającej większości obliczeń na tyle małe dla trzysetnej sekundy od momentu zainicjowania pożaru, że nie miałyby wpływu na analizę ewakuacji osób z zagrożonej przestrzeni. W przeprowadzonych obliczeniach zaobserwowano również, że $w$ przypadku scenariuszy $z$ taką samą istotny wpływ na sposób oceny ma fakt, w jakim miejscu zostaje ukształtowana główna struga powietrza dopływająca z szachtu nawiewnego do wyciągowego. Jeżeli struga ta napotyka na swojej drodze przeszkody w postaci pojazdów o różnej wielkości lub kształcie, wtedy znacznie wzrastają rozbieżności pomiędzy analizowanymi scenariuszami, na przykład w masowej koncentracji dymu w przestrzeni garażu.

W przypadku garaży o skomplikowanym kształcie lub garaży niskich (poniżej 2,9 lub z licznymi lokalnymi obniżeniami poniżej 2,7 m,np. jak w garażu nr 2) rekomenduje się wykonanie dodatkowych obliczeń numerycznych uwzględniających różną liczbę pojazdów i ich lokalizację w przestrzeni garażu. Dodatkowe symulacje można ograniczyć do przypadków, w których zajętość miejsc parkingowych w garażu będzie wynosiła $0 \%$ (tylko samochód, z którego inicjowany jest pożar), 40-50\% i 100\%. Podane procentowe obłożenie stanowisk wynika z przeanalizowanych serii obliczeń i sytuacji, gdy różnice w wynikach były najbardziej zauważalne $\mathrm{i}$ istotne $\mathrm{w}$ procesie oceny.

Różnice w wynikach pomiędzy scenariuszami będą większe, gdy pożar będzie się rozwijał z większa mocą i w rezultacie wydzieli się więcej dymu i ciepła w przestrzeni garażu. Dlatego istotne jest, by w takim przypadku, przed przystąpieniem do obliczeń numerycznych, dokonać oceny ryzyka wpływu zajętości miejsc postojowych na wyniki końcowe. Z przedstawionych w niniejszym opracowaniu symulacji wynika, że już przy pożarach rzędu 1,4 MW w początkowej fazie rozwoju pożaru istotnie mogą zmieniać się warunki panujące w garażu.

W sytuacji, gdy prędkości na kratach nawiewu mechanicznego wynoszą ponad 2,5 m/s, a w najbliższej okolicy szachtu kompensacyjnego znajdują się zaparkowane pojazdy, wówczas obliczenia numeryczne należałoby wykonać dla pustego garażu, jak również dla scenariusza z samochodami zaparkowanymi w tych newralgicznych punktach. Uzyskane z takiej serii obliczeń wyniki mogą się znacząco różnić, więc zasadne jest by uwzględniać tego rodzaju przypadki w analizach.

Badania dotyczące wpływu przeszkód na końcowe wyniki symulacji CFD będą kontynuowane. Kolejnym etapem prac

\section{Conclusions}

This paper analyses the influence of parked vehicles on the spread of smoke and hot fire gases in an indoor car park. The study presents two different models of enclosed underground car parks with numerical models for various heat release rates: 1.4 MW and 4.2 MW. An analysis of the simulations performed demonstrates that the values of the air turbulences generated in the car park (with diameters by far exceeding the height of the car park) and the high flow velocity in these turbulences, have a significant effect on the mass concentration of smoke in the studied area. For the temperature field, the differences between simulations adopting different occupancy rates of parking spaces are so small for the vast majority of calculations in the 300th second after ignition that they would have no effect on the analysis of evacuation of people from the danger area. The calculations performed also demonstrated that for scenarios with the same occupancy rate, the assessment method is highly influenced by the location where the main air stream from the air supply duct to the exhaust duct is formed. If the air stream encounters obstacles in the form of vehicles of various sizes or shapes, then the differences between the analysed scenarios become more exaggerated, for example in terms of the mass concentration of smoke in the car park area.

For car parks with a complex shape or low car parks (below $2.9 \mathrm{~m}$ or with various local drops below $2.7 \mathrm{~m}$, such as in car park No. 2) it is recommended to perform additional numerical calculations taking into account various numbers of cars and their locations in the car park area. Additional simulations may be limited to cases where the occupancy rate of parking spaces in the car park is $0 \%$ (only the car in which the ignition source is located), $40-50 \%$ and $100 \%$. The said percentage occupancy rates for parking spaces are based on the analysed series of calculations and situations where the differences in results were the most noticeable and significant in the assessment process.

Differences in results across scenarios will be greater if the fire develops with a higher heat release rate and as a result more smoke and heat is generated within the indoor car park. For this reason, it is important to assess the risk of the influence of occupancy rates on the final results prior to performing the numerical calculations. The simulations presented in this study demonstrate that for fire sizes starting from 1.4 MW at the early stage of fire development, the conditions present in the car park may be subject to significant changes.

Where the velocities at mechanical air supply grilles exceed $2.5 \mathrm{~m} / \mathrm{s}$ and vehicles are parked in the close vicinity of the compensation inlet, the numerical calculations should be performed for an empty car park, as well as for a scenario with cars parked in critical locations. The results obtained in such a series of calculations may differ significantly, so it is reasonable to include such cases in the analyses.

Studies of the influence of obstacles on the final results of CFD simulations will be continued. The next stage will be to verify temperature fields during a rescue and firefighting operation, as well as to analyse the situation in indoor car parks with 
będzie m.in. weryfikacja pól temperatur w czasie prowadzenia akcji ratowniczo-gaśniczej, jak również analiza sytuacji w garażach z zaprojektowaną instalacją oddymiającą kanałową. Dodatkowo zostaną sprawdzone scenariusze, w których występuje np.: tylko jeden rodzaj pojazdów. Jest to konieczne do oceny wpływu wielkości typu pojazdu na uzyskane wyniki.

Artykuł został opracowany w ramach prac statutowych ITB nr NZP-115.

\section{Literatura / Literature}

[1] Węgrzyński W., Tofiło P., Porowski R., Hand calculations, zone models and CFD - areas of disagreement and limits of application in practical fire protection engineering, SFPE 11th Conference on Performance -Codes and Fire Safety Design Methods, 2016, DOI: 10.13140/ RG.2.1.4974.3604.

[2] Hurley M.J., Gottuk D.T., Hall J.R., Harada K., Kuligowski E.D., M. Puchovsky, Torero J.L., Watts J.M., Wieczorek C.J. (red.), SFPE Handbook of Fire Protection Engineering, 5th ed., Springer New York, New York 2016, doi:10.1007/978-1-4939-2565-0.

[3] Report BD2552 Fire Spread in Car Parks, Building Research Establishment, 2009, 2010.

[4] Joyeux D., Kruppa J., Cajot L.-G., Schleich J.-B., van de Leur P., Twilt L., Demonstration of real fire tests in car parks and high buildings, Final Report, Komisja Europejska Luksemburg, 2002.

[5] Janssens M.L., Development of a database of full- scale calorimeter tests of motor vehicle burns, Southwest Research Institute, USA 2008.

[6] Collier P.C.R., Car Parks - Fires Involving Modern Cars and Stacking Systems, BRANZ Study Report, 2011.

[7] Tilley N., Deckers X., Merci B., CFD study of relation between ventilation velocity and smoke backlayering distance in large closed car parks, "Fire Safety Journal" 2012, 48.

[8] Deckers X., Haga S., Tilley N., Merci B., Smoke control in case of fire in a large car park: CFD simulations of full-scale configurations, “Fire Safety Journal" 2013, 57, 22-34, https://doi.org/10.1016/j.firesaf.2012.02.005.

[9] Partanen M., Heinisuo M., Car fires with sprinklers: a study on the Eurocode for sprinklers, [w:] Proceedings of International Conference in Prague 19-20 April 2013 Application of Structural Fire Engineering, F. Wald, I. Burgess, K. Horova T., Jana, J. Jirku (red.), Czech Technical University in Prague, Prague 2013.

[10] Halada L., Weisenpacher P., Glasa J., Computer Modelling of Automobile Fires, [w:] Advances in Modelling of Fluid Dynamics, 2012, http:// dx.doi.org/10.5772/48600. a duct-based smoke exhaust system. In addition, scenarios with, e.g. only one type of vehicles will be studied. This is necessary for the assessment of the influence of vehicle type (size) on the obtained results.

The article was written within statute works of Budilding Research Institue No. NZP-115.

[11] BS 7346-7: Components for smoke and heat control systems Code of practice on functional recommendations and calculation methods for smoke and heat control systems for covered car parks.

[12] Magnusson S.E., Risk Assessment, [w:] Fire Safety Science - Proceedings of the Fifth International Symposium, Y. Hasemi, 1997, 41-58.

[13] Tohir M.Z.M., Spearpoint M., Development of fire scenarios for car parking buildings using risk analysis, [w:] Fire Safety Science - Proceedings of the Eleventh International Symposium, 2014, 944-957.

[14] The International Council on Clean Transportation, European Vehicle Market Statistics Pocketbook 2016/17, Berlin 2016.

[15] Case No COMP/M.1406 - HYUNDAI / KIA, Regulation (EEC) no 4064/89 Merger procedure, 17.03.1999.

[16] NEN 6098:2012 Rookbeheersingssystemen voor mechanisch geventileerde parkeergarages, 2012.

[17] Rozporządzenie Ministra Infrastruktury z dnia 12 kwietnia 2002 r. w sprawie warunków technicznych, jakim powinny odpowiadać budynki i ich usytuowanie, wraz z późniejszymi zmianami (Dz.U. $2002 \mathrm{Nr} 75$, poz. 690).

[18] Węgrzyński W., Konecki M., Influence of the fire location and the size of a compartment on the heat and smoke flow out of the compartment, [w:] AIP Conf. Proc. 1922 (2018), 110007, http://dx.doi. org/10.1063/1.5019110.

[19] ANSYS, ANSYS Fluent 14.5.0 - Technical Documentation, 2014.

[20] Krajewski G., Węgrzyński W., The use of Fire safety Engineering in the design and commissioning of car Park Fire ventilation systems, BiTP Vol. 36 Issue 4, 2014, http://dx.doi.org/10.12845/bitp.36.4.2014.15.

[21] Węgrzyński W., Krajewski G., Systemy wentylacji pożarowej garaży, [w:] Projektowanie, ocena, odbiór nr 493/2015, Instytut Techniki Budowlanej, Warszawa 2015.

[22] Węgrzyński W., Vigne G., Experimental and numerical evaluation of the influence of the soot yield on the visibility in smoke in CFD analysis, "Fire Saf. J." (2017) 91, 389-398, doi:10.1016/j.firesaf.2017.03.053. 
MGR INŻ. PRZEMYSŁAW SUCHY - specjalizuje się w wentylacji pożarowej garaży oraz w metodach probabilistycznych w bezpieczeństwie pożarowym. Ekspert w modelowaniu przepływów w skomplikowanych układach wentylacyjnych oraz optymalizacji scenariuszy działania systemów wentylacji pożarowej.

DR INŻ. WOJCIECH WĘGRZYŃSKI - specjalizuje się w dużych obiektach handlowych oraz tunelach komunikacyjnych. Ekspert w zakresie wpływu elementów architektury budynków na przepływ dymu. Międzynarodowy instruktor stowarzyszenia SFPE w zakresie zaawansowanych analiz CFD w programie FDS. Zainteresowania naukowe: przepływ dymu w obiektach budowlanych, modelowanie widzialności w dymie, uwzględnienie warunków atmosferycznych w modelowaniu pożarów oraz optymalizacja systemów wentylacji pożarowej. Członek komitetów normalizacyjnych CEN TC191/SC1/WG 5 i WG 9.
PRZEMYSŁAW SUCHY, M.SC. ENG. - specialises in the fire ventilation of indoor car parks and in using probabilistic methods for fire safety applications. Expert in flow modelling for complex ventilation configurations and in optimising scenarios for the operation of fire ventilation systems.

WOJCIECH WĘGRZYŃSKI, PH.D. ENG. - specialises in large commercial buildings and transport tunnels. Expert in the field of assessing the impact of a building's architectural elements on smoke flow. International SFPE instructor of advanced CDF analysis using the FDS software. Scientific interests: smoke flow in civil structures, modelling visibility in smoke, adjusting for weather conditions in fire modelling and optimising fire ventilation systems. Member of the CEN TC191/SC1/WG 5 and WG 9 standardisation committees. 